$1-1-1925$

\title{
A Study of the Breeding Records of a Group of Shorthorn Cows
}

\author{
C. V.Wilson
}

Follow this and additional works at: https://researchrepository.wvu.edu/ wv_agricultural_and_forestry_experiment_station_bulletins

\section{Digital Commons Citation}

Wilson, C. V., "A Study of the Breeding Records of a Group of Shorthorn Cows" (1925). West Virginia Agricultural and Forestry Experiment Station Bulletins. 198.

https://researchrepository.wvu.edu/wv_agricultural_and_forestry_experiment_station_bulletins/198 @ WVU. It has been accepted for inclusion in West Virginia Agricultural and Forestry Experiment Station Bulletins by an authorized administrator of The Research Repository @ WVU. For more information, please contact ian.harmon@mail.wvu.edu. 
West Virginia University Libraries

$$
\text { a }
$$




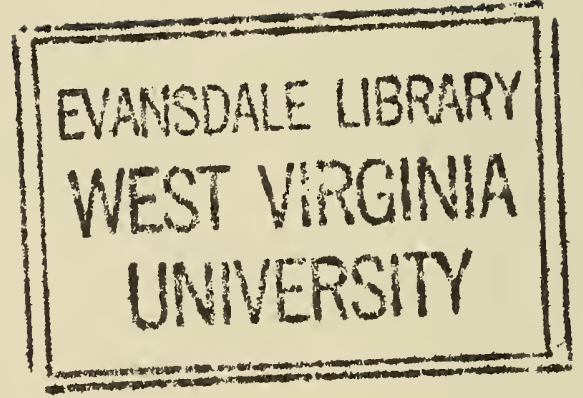


Restricted

Circulation Only

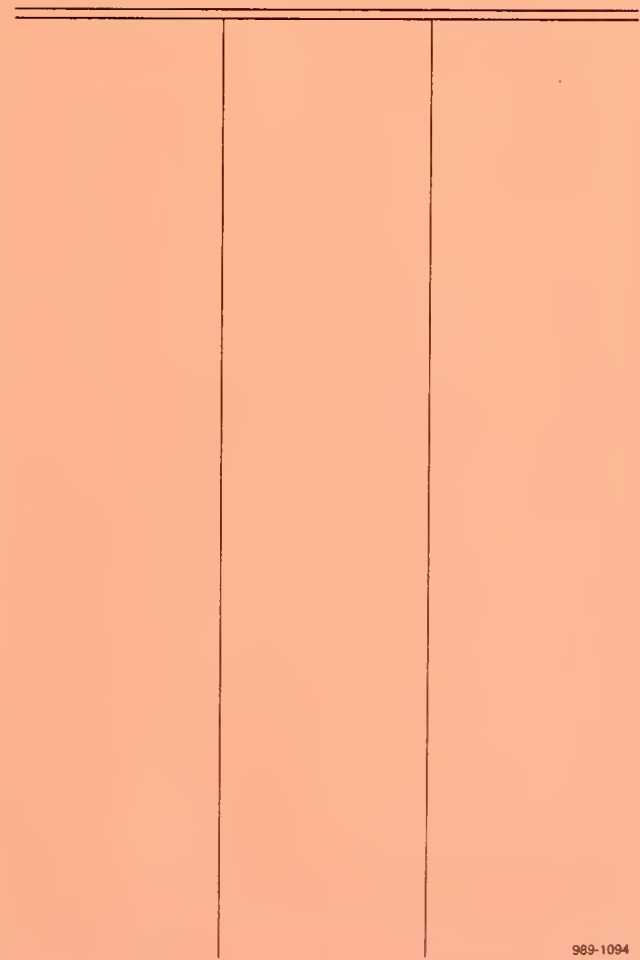





\title{
Agricultural Experiment Station
}

College of Agriculture, relest Virginia Finibersity

\author{
HENRY G. KNIGHT, Director
}

Morgantown

\section{A Study of the Breeding Records}

\section{of a Group of Shorthorn Cows}

\section{(Technical)}

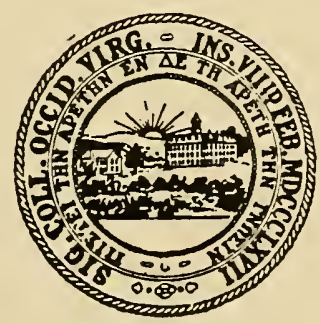




\section{AGRICULTURAL EXPERIMENT STATION STAFF}

FRANK BUTLER TROTTER, A. M., LL. D. -..... President of the University GEORGE R. LYMAN, Ph. D. ........ Dean of the College of Agriculture HENRY G. KNIGHT, Ph. D. Director of the Experiment Station WALTER C. SCHNOPP, B. S. Agr. JOHN C. JOHNSTON

Agricultural Editor Chief Clerk

\section{AGRONOMY}

R. J. Garber, Ph. D.

T. E. Odland, M. S. Associate Agronomist

T. C. MeIlvaine, Ph. D. $\dagger$ Assistant Agronomist

M. M. Hoover, M. S. Junior Agronomist H. K. Rowley, B. S. Agr.** Seed Analyst

\section{ANIMAL HUSBANDRY}

E. A. Livesay, M. S.

Animal Husbandman

Chas. V. Wilson, M. S. Assistant Animal Husbandman

E. C. Stillwell, M. S. Assistant Animal Husbandman

R. H. Tuckwiller, B. S. Agr.* Assistant Animal Husbandman

\section{CHEMISTRY}

Henry G. Knight, Ph. D.

Chemist

R. B. Dustman, Ph. D.

Assistant Chemist

Chas. E. Weakley, Jr., B. A.

T. B. Leith, B. A.** Assistant Chemist

T. J. Cochran, B. S.

Assistant Chemist Junior Chemist

\section{DAIRY HUSBANDRY}

Ernest L. Anthony, M. S. Agr.

Dairy Husbandman

H. O. Henderson, M. S. Agr.

Associate Dairy Husbandman Warren Gifford, B. S. Agr. $+\dagger$

Junior Dairy Husbandman

G. M. Trout, M. S.

Assistant in Dairy Husbandry

\section{ENTOMOLOGY}

L. M. Peairs, Ph. D.

W. E. Rumsey, B. S.

Entomologist

State Entomologist
FARM ECONOMICS

A. J. Dadisman, Ph. D.

Paul A. Eke, Ph. D.

Farm Economist

Junior Farm Economist

F. D. Cornell, M. S.

Junior Farm Mechanician

W. W. Armentrout, M. S.

Junior Farm Economist

Ruth Buchanan, Ph. D.

\section{HOME ECONOMICS}

Home Economist

HORTICULTURE

M. J. Dorse: $r$, Ph. D.

H. L. Crane, M. S. Agr.

Horticulturist

Associate Horticulturist

H. E. Knowlton, Ph. D.

Associate Horticulturist

K. C. Westover, M. S. Agr.

Asisistant Horticulturist

Ernest Angelo, B. S. Agr.

Junior Horticulturist

L. F. Sutton, B. S. Agr. $\dagger$

Assistant Horticulturist

Troy M. Currence, B. S. Agr.t†

Assistant in Horticulture

PLANT PATHOLOGY

N. J. Giddings, Ph. D.

Anthony Berg, M. S.

Plant Pathologist

Assistant Plant Pathologist

L. H. Leonian, Ph. D.

Assistant Plant Pathologist

E. C. Sherwood, M. S.

Assistant Plant Pathologist

POULTRY HUSBANDRY

Horace Atwod, M. S. Agr.

Poultry Husbandman

E. P. Deatrick, Ph. D.

SOILS

Associate Soil Technologist

\footnotetext{
*In co-operation with the U. S. Department of Agriculture, Washington, D. C.

**In co-operation with the State Department of Agriculture, Charleston, W. Va.

***Resigned September 1, 1925.

$\dagger$ In charge of the Reymann Memorial Farms, Wardensville, W. Va.

$\$$ In charge of the Maggie Sub-Station, Maggie, W. Va.

††On leave of absence.
} 


\section{A Study of the Breeding Records of a Group of Shorthorn Cows*}

Of all the various phases of animal breeding no one, perhaps, is of more vital concern to the breeder than that included under the terms fecundity and prolificacy. No breeder may succeed with any breed of livestock, and the breed itself cannot endure, unless the females of the breed reproduce abundantly. Individual excellence, pedigree, and performance, of any description, aside from reproduction, all count for nothing in the presence of total barrenness, from any cause whatsoever. Breeders must have numbers. The proliferation of a species is now and always has been the major work of breeders of domestic animals. It is true enough that the better breeders all seek to produce animals possessing desirable qualities and to avoid the less desirable ones but even these men will fail if their improved animals are not capable of abundant reproduction.

Practically speaking, the application of modern methods of breeding for improvement of domestic animals dates from the time of Robert Bakewell who inaugurated his work about 1760 with a result little short of marvelous for his time. Previous to Bakewell's operations most of such improvement as had been wrought was from chance or accident rather than from design, and livestock breeding was still for the most part merely the propagation of animals. But as soon as Bakewell's work became known to his contemporaries a a dynamic change came over livestock breeds and breeders.

In fact real breeds, as such, were first developed by Bakewell and his contemporaries. Following closely one upon another, improvement upon improvement came to pass, new laws of animal breeding were discovered, new principles of breeding were applied, until today representative animals of various breeds are produced so nearly true to type that further advance by breeders is difficult if not impossible unless the breeder be grounded most thoroughly in the underly-

* The writer desires to express his indebtedness to The American Shorthorn Breer.ers' Association, Chicago, Illinois, for the use of its records and files, and to the association secretary, P. K. Groves, assistant secretary, J. F. Groves, and fieldman, J. L. Tormey for their interest and help in seucring data. Acknowledgements are also due to Professor P. S. Shearer, under whose direction this study was made at Ames, Iowa, as part of the requirements for a master's jegree, and to Professor $H$. $H$. Kildee, vice dean and head of the Department of Animal Husbandry, Iowa State College of Agriculture, for their encouragement and assistance. 
ing principles of breeding, the history of the breed development, and the tendency, faults, and virtues of the strains and tribes within the breed.

For a little less than two hundred years now, we have had separate breeds of cattle. Throughout this time the laws, principles, and new discoveries have been applied to cattle breeding, with the result of making the cattle of today more nearly meet the demands of man than ever before. Yet, despite these facts, cattle in general are not any more prolific than they were two hundred years ago. In fact it appears from certain evidence that they are even less prolific. It has been said that barrenness does not attract so much attention especially in the females of beef breeds since barren beef-bred cows may be sent to the butcher and an economic loss be averted thereby. This argument has certain elements of truth in it. But these truths caninot be nuade to apply to our more highly improved and, therefore, mote valuable pure-bred females of the beef breeds. If these fail to breed the improvement wrought to date dies with them. If barrenness becomes prevalent in any tribe or strain within a breed that tribe or strain and its particular valuable qualities are in danger of extinction. It the tribe does not become extinct then the valuable characteristics that set it apart are all too often dissipater. If one accept the statement that a breeder must have numbers, and further, that a breed, tribe, or strain is in danger of extinction or dissipation without numbers, then authentic information that will show the rate of reproduction, its character, and the relation or non-relation of other circumstances incident to reproduction should be of interest and value to both the breeder and the student. This is the underlying thought and the incentive for making and presenting "A Study of the Breeding Record of a Selected Group of Shorthorn Cows."

\section{THE BREEDING RECORDS}

\section{Plan of Study}

This study was undertaken for the purpose of securing definite facts in regard to the breeding performance of registered Shorthorn cows. The cows to be selected were all to have been registerd in the American Shorthorn Breeders' Association herd books and calved within one calendar year, January 1 to December 31, inclusive. All cows were to have been calved at least twelve years prior to inauguration of study.

The first cow chosen for study under this plan to be the first registered cow whose date of birth occurred in the year chosen. Each 
cow thereafter with the sane "year-clate of birth" as the first cow chosen to be added until the arbitrary number of 10,000 cows were selected.

The breecting record of the cows to be secured from the Produce Record Cards, on file in the office of The American Shorthorn Breeders' Association, Chicago, Illinois. The data taken from the herdbroks of The Shorthorn Breeders' Association for each cow to be as follows :

(a) Register number.

(b) Name.

(c) Month calved.

(d) Name of cow's sire.

The data taken from the Produce Record Cards for each cow, if any produce, to be as follivis:

(a) The month ind year of birth of first calf.

(b) The month and year of birth of last calf.

(g) The number of bull calves.

(h) The number of cow calves.

(i) Cows registered as one of twins to be especially noted for study.

\section{Objects of Study}

1. To obtain the average ntmber of registered calves produced by a twelve-year-old class of cows.

2. To separate into groups the cows producing none, one, two, three, or more calves, up to the group that produced a calf each year.

3. The compilation of the "calf each year" class of couvs.

4. A study of the twin class of cows with reference to prolificacy.

5. To secure data showing the prolific period in tivelve-yearold cows and the average age they may be expected to decline in productivity.

6. To secure data on the earliest age, average age, and oldest age, that practical breeders mate their heifers.

7. To show the sex ratio of registered bull to cow calves.

8. To determine tribe, strain, or family of exceptional producers.

9. To show season of year breeders have their calves dropped.

\section{Method of Procedure}

In accordance with the plan of study outlined, Shorthorn cows 
calved in the calendar year 1908, January 1 to December 31 were chosen for study. Although this choice was arbitrary the method of registration of Shorthorn cattle had a large bearing on the choice of the year.

From the time the herd register of The American Shorthorn Breeders' Association was started until Volume 69 was published, January 22, 1907, cows were registered under the English form. They were referred to by Volume and page number. A new form was put into effect at the time Volume 70 was published. The cows were kept separate from the bulls as before, but were recorded under consecutive numbers. The form was further condensed and improved by using columns for each item of data. This form of registration made possible the rapid separation of cows born within a calendar year. This form was continued until Volume 90 was issued, April 2, 1916, approximately eight years after Volume 70.

Cows could be regularly registered under a rule passed in 1901, effective 1903, until they were three years old. Thereafter the penalty was $\$ 10.00$. This rule was in force until January 10,1916 , when the age limit of regular registration, without penalty, was reduced to one year.

The first cow calved in 1908 to appear in the herdbook is Harriet Ann 23932, Volume 72. She, therefore, was the first cow selected for this study. Data on each cow registered in Volume 72 and volumes thereafter, calved in 1908, were transcribed to special forms prepared for the purpose until 10,000 cows calved in 1908 had been selected. The last cow transcribed was number 76407 . Freda 5 th, by Beauty Boy, Volume 76, which was closed April 20, 1910.

The selection from successive volumes is listed in Table I.

\section{TABLE I.-Number and Per Cent. of Cows Calved in 1908 as Se- lected from Volumes 72 to 76 Inclusive.}

\begin{tabular}{c|c|c|c|c}
\hline $\begin{array}{c}\text { No. of Cows Numbered } \\
\text { Volume } \\
\text { Inclusive }\end{array}$ & $\begin{array}{c}\text { Nat Number } \\
\text { Cows in Volume }\end{array}$ & $\begin{array}{c}\text { No. of 1908 } \\
\text { Cows in Voume }\end{array}$ & $\begin{array}{c}\text { Par Cent 1908 } \\
\text { Cows in Volume }\end{array}$ \\
\hline 72 & 23001 to 25000 & 12000 & 133 & 1.10 \\
73 & 35001 to 47000 & 12000 & 1417 & 11.81 \\
74 & 47001 to 58000 & 11000 & 2663 & 24.21 \\
75 & 58001 to 70000 & 12000 & 3628 & 30.23 \\
76 & 70001 to 81000 & 11000 & $2159 *$ & $33.37^{* *}$ \\
\hline
\end{tabular}

* Number of 1908 cows selected out of 6106 , Volume 76.

** Percentage of 1908 cows in 6406 .

From estimates given elsewhere, between 23,000 and 24,000 cows 
were registered as calved in 1908 . The 10,000 in this study were approximately all registered before they calved, and before the memories of their owners were in much danger of mixing dates, as is possible in long delayed registrations.

A ruled form was prepared for the transcription of data from the herdbooks and from the Produce Record Cards in such form as would contain the proposed items of data for each cow as listed under the plan of study.

The record number, name, month, date of birth, and name of sire were copied from the herd records for each cow calved in 1908 starting with 23932 and ending with 76407. The 10,000 cows of 1908 were thus separated from a total number of 58,000 cows.

Once separated by transcription to the data sheets, the next step in procedure was the transcription from the Produce Record Cards. These cards are on file in the office of The American Shorthorn Breeders' Association, Chicago, Illinois. They are filed alphabetically according to the name of the cow and that of her sire. Thus Mary Ann by Adam is in advance of Mary Ann by Baxter. Again, there are two files of these cards. One file, the so called "Active File," contains cows that have produced calves prior to a given time limit, which is determined by the secretary of the association. Whenever the active files become crowded they are inspected for cows that have had no produce, or no produce within five years from date of last inspection and these inactive Produce Record Cards are removed from the active files and are refiled in the so called "Inactive File." Thus the frequently used files are freed from useless cards, but should any cow calve whose card has been so removed, her record card is available for use.

The active file cards were all examined and the inactive file was examined by sampling. The cow's cards making up the fifth and tenth thousands respectively were used to sample the inactive file and the data from the inactive files were calculated from these cards as it affected certain items.

The items of data for the 10,000 cows included in this study were obtained within the period of time July 10, 1921, to July 19, 1922. The records for approximately half of the cows were obtained July 10, 1921, to September 1, 1921, and for the remaining one-half June 10, 1922, to July 191922.

\section{Productive and Non-Productive Cows}

As previously explained any registered Shorthorn cow produc- 
ing a calf, that is later registered, is credited with the calf on her Produce Record Card. An examination of these cards disclosed that 5,560 cows produced one or more calves up until July 19, 1922, and that 4,440 cows were without registered produce.

The facts presented are doubtless contrary to the opinion commonly held that approximately all registered cows produce one or more calves which are registered.

No data were available upon which to base an estimate of the percentage of cows failing to produce registered calves, with reference to any given cause. In the absence of such data a list of probable causes that may properly be considered in an attempt to explain the failure of such a large percentage of cows to produce registered calves is appended. While such a list is merely suggestive, it is based upon causes that are more or less experienced by all cattle breeders and practicing veterinarians. In no instance has any probable cause been assigned that does not have facts to support it. That registered calves were not produced does not necessarily mean that all of the 44.4 per cent were barren, nor does it mean that they failed to calve. It is true, however, in so far as this group is concerned that registered cattle and whatever tribe or strain the group represents will make no further progress through such cows. Whether they were all culls or whether many of them possessed valuable potentialities for breed improvement does not change matters, they were lost to the breed.

The following suggestive list of causes of failure to produce registered calves, on the part of the non-productive cows, is arbitrarily grouped and presented for convenience.

Group I.-Cow calves that died after registration and before being bred, from :

(1) Infectious and contagious disease.

(2) Parasites.

(3) Accidents.

Group II.-Cows that were bred and discarded before or after the expiration of their first gestation period because of :

(1) Failure to become pregnant from any cause after repeated service.

(2) Injury at time of service

(3) Abortion, contagious or accidental.

(4) Death before, during, or after parturition due to the various difficulties attendant thereto.

(5) Death of first calf, calving a monstrosity. 
(6) Mammary trouble such as milk fever and garget.

(7) Accidental conception to scrub, grade, or dairy bred sire.

(8) Malnutrition of dam or offspring before or during gest: tion.

(9) Off type, undesirable markings, or unsatisfactory development during gestation.

(10) Market demand brought about by fads, market conditions, or financial conditions affecting only the breeder and owner or breeders in general.

Group III.-Cows that failed to come in heat or whose periods of oestrum were not observed and that did not conceive when served on account of :

(1) Barrenness from any cause.

Group IV.-Cows excluded from production of registered offspring intentionally or unintentionally by their breeder or owner by reason of being:

(1) Owned by men who did not record offspring.

(2) Sold as purebred but without registration certificate.

(3) Slaughtered for any reason.

\section{The Calving Record of 5,560 Producing Shorthorn Cows}

The profits that a breeder may derive from breeding registered cattle is in a degree dependent upon more than mere numbers of registered calves. The real breed improver recognizes the truth of such a statement, and he, as well as other breeders strives to build up a herd of cows that breed regularly and produce offspring with merit and excellence at each calving rather than an occasional individual and in between times, modiocre or inferior calves.

Dean C. F. Curtis, (1918) Ames, Iowa, who by reason of his position, as educator and breeder, has given much thought to the type of matrons real breeders seek, makes some statements that may be profitably pondered over by not only the new or inexperienced breeder but by all other breeders as well. Dean Curtis says, "It is not the price that deterinines the value of a breeding cow. In nearly every one of the top herds of all breeds, I dare say that the breeder who is entirely familiar with the produce of that herd could pick from two to five outstanding matrons of proven excellence, worth as much in making herd improvement in the herd as all the rest of the herd combined.

"The best herds are built from a foundation of a comparatively 
few outstanding females mated with good sires. Even the most experienced breeders seldom know which cows belong to this class until they have proven themselves by their produce."

All breeders know that merely because a calf is registered is not sufficient reason to claim that it is of the highest merit. It does seem, however, that there is good reason to believe that all the better calves in each breeder's herd are registered. Granted that the registered calves from a cow is some measure of her ability as a producer of high class cattle, one has at least a means by which he may compare cows, and perhaps a means by which he may in a degree determine their value or if "By their fruits ye may know them," or as Dean Curtis has stated, "They prove themselves by their produce," then the number of registered calves a cow has produced over a decade or more is in no small degree an indication of her value as a breeding cow and in some degree a breed improver.

It has been shown previously that 4,440 cows of the 10,000 did not produce calves which were registered. This 44.4 per cent is lost to the breed. It now remains to show the performance of the 5,560 or 55.6 per cent that did produce one or more registered calves.

Methods of Study.-The 5,560 cows were divided into eleven groups corresponding to the number of calves produced, from one calf per cow, the lowest calving group, to eleven calves per cow, the highest number found for the time interval, 1909 to 1922, included in the data.

Results of Study.-The results of the division are given in Table II.

TABLE II.-5,560 Shorthorn Cows and the 22,275 Calves Produced by Them, 1909-1922.

\begin{tabular}{c|c|c|c|c|c|c}
\hline $\begin{array}{l}\text { Calves } \\
\text { Per Cow }\end{array}$ & $\begin{array}{c}\text { Number } \\
\text { Cows }\end{array}$ & $\begin{array}{c}\text { Per Cent } \\
\text { Cows }\end{array}$ & $\begin{array}{c}\text { Cumula- } \\
\text { tive } \\
\text { Per Cent }\end{array}$ & $\begin{array}{c}\text { Number } \\
\text { Calves }\end{array}$ & $\begin{array}{c}\text { Per Cent } \\
\text { Calves }\end{array}$ & $\begin{array}{c}\text { Cumula- } \\
\text { tive } \\
\text { Per Cent }\end{array}$ \\
\hline 1 & 1185 & 21.1 & 21.1 & 1185 & 5.3 & 5.3 \\
2 & 790 & 14.2 & 35.3 & 1580 & 7.1 & 12.4 \\
3 & 655 & 11.8 & 47.1 & 1965 & 8.8 & 21.2 \\
4 & 660 & 11.9 & 59.0 & 2640 & 11.9 & 33.1 \\
5 & 645 & 11.6 & 70.6 & 3225 & 14.5 & 47.6 \\
6 & 640 & 11.5 & 82.1 & 3840 & 17.2 & 64.8 \\
7 & 405 & 7.3 & 89.4 & 2835 & 12.7 & 77.5 \\
8 & 320 & 5.8 & 95.2 & 2560 & 11.4 & 88.9 \\
9 & 170 & 3.1 & 98.3 & 1530 & 6.9 & 95.8 \\
10 & 75 & 1.4 & 99.7 & 750 & 3.4 & 99.2 \\
11 & 15 & .3 & 100.0 & 165 & .8 & 100.0 \\
\hline \hline
\end{tabular}

From Table II it will be observed that almost half of the producing cows 47.1 per cent produced but a trifle more than one-fifth 
of the calves. The +7.1 per cent of the cows include the groups calying 1,2, and 3 calves. The groups, 4, 5, 6 are equivalent to 42.3 per cent of the cows and they calved 56.3 per cent of the calves. Groups $8,9,10$, and 11 equal only 10.6 per cent of the cows but they calved 22.4 per cent of the total calves.

Corrs calving but one or two registered calves can hardly be connted outstanding performers or even profitable producers. Indee', there are ample reasons to suspect that many of such cows were little, if any, more profitable than high-grade cows. As evidence of this the year of calving each cow's one registered calf is given for the 1.185 cows in Table III.

\section{TABILE III.-1,185 Cows Calving One Registered Calf.}

\begin{tabular}{l|r|r|r|r|r|r|r|r|r|r}
\hline \hline Year & 1910 & 1911 & 1912 & 1913 & 1914 & 1915 & 1916 & 1917 & 1918 & 1919 \\
\hline Cows & 270 & 400 & 320 & 80 & 70 & 65 & 20 & 15 & 25 & 20 \\
\hline \hline
\end{tabular}

It is not probable that cows calving their first registered calf after 1912 were kept for the one registered calf they produced. The most platusible explanation is, that these cows' calves were not registeren except an occasional calf purchased by some one that desired a registration certificate for the prestige it conferred on his purchase. It is worthy of note that approximately one-half of the 1,185 "onecalf" cows were credited with bulls and the other one-half with cow calves on their cards.

One cannot but sispect that the rising and high values of registered Shorthorns of $19 \mathrm{i}$ \% to 1919 was in a measure responsible for the calves being registered from cows that had been relegated to the graile herts.

Figure 1 gives a graphic comparison of the groups of cows. This chart shows that the number of cows per group declines as the number of regsistered calves per cow increases. It should be kept in mind that there will be a very few cows that will have continued to produce calves for several years after this study was completed. The number that nuy be expected to calve fifteen or more calves will in all probability fall below one-tenth of one per cent of the 10,000 cows studied or less than ten cows.

Figure 2 is furnished for comparison of the groups of cows and their calves.

The averase number of calves per cow is 4.0062. The decimal is negligible and is, therefore, disregarded. As a result the average 
calves per cow for the 5,560 cows is shown where the "calves per cow" curve crosses the curve for the cows. It so happens that the calves produced by Group 4 and the cows of Group 4 each equal 11.9 of their respective totals, that is, 22,275 calves and 5,560 cows.

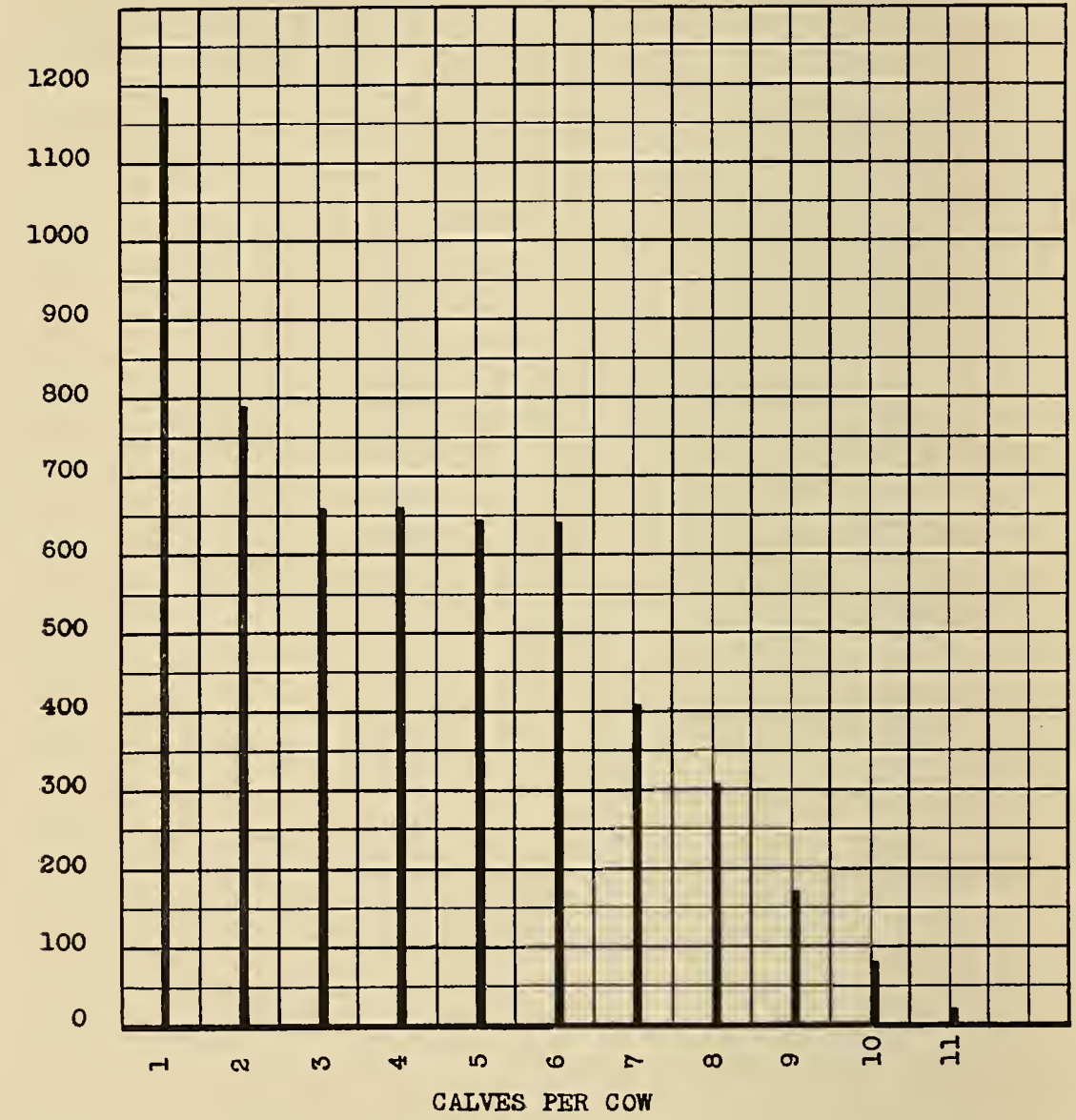

Fig. 1.-10,000 Shorthorn Cows Calved 1908; 5,560 Cows Grouped with Reference to Calves Produced.

The mean for the cows falls approximately one-third of the distance along that part of the curve for the cows connecting the third and lourth groups.

The mean for the calves is located a trifle past group 5 .

The modal group of the calves is group 6 .

Cows producing five or more calyes per cow are studied in an- 
other section of this paper; likewise part of the cows that produced nine and ten calves.

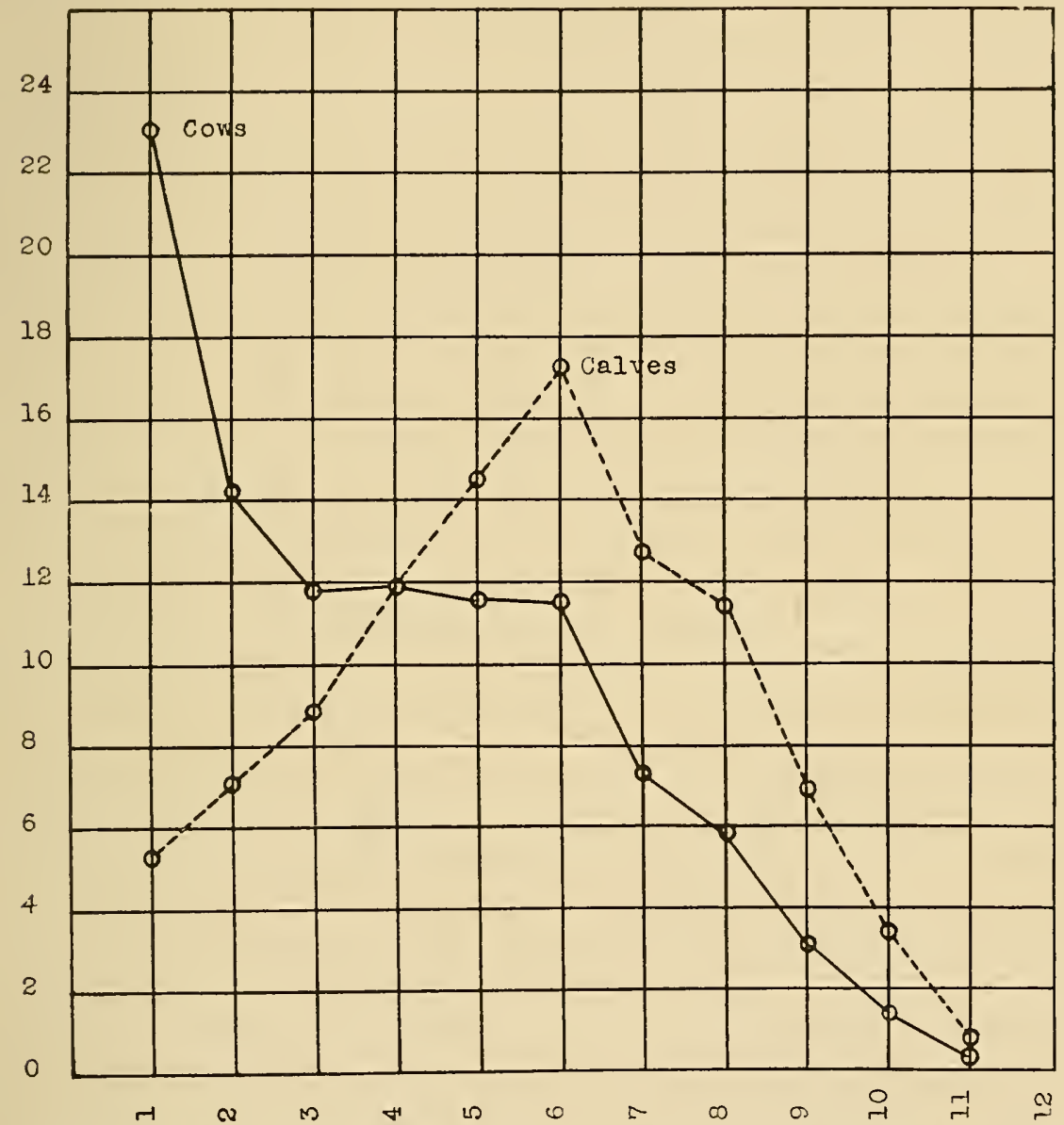

Fig. 2.-5,560 Producing Shorthorn Cows and the Calves per Cow by Groups. The Cows are Shown by Percentages and the Calves by Numbers.

The curves for the cows and their calves when studied jointly bring out the fact that a large group of the cows, groups 1, 2, and 3, had a very small group of calves, that the groups of cows producing four to eight calves inclusive are the groups upon which the breed is dependent for the major portion of its calves and that the groups 9, 10 , and 11 , containing 260 cows actually produced half as many calves as the 2,630 cows in groups 1,2, and 3 .

If group 1, 2, and 3 be compared with $8,9,10$, and 11 it is found 
that 2,630 cows in the 1,2 , and 3 calf per cow groups produced 4,730 calves and 560 cows in the 8 to 11 groups produced 5,005 . Thus more than 2,630 cows in the 1,2 , and 3 groups are required even to approximate the result, obtained by breeders, in terms of registered calves, for the groups $8,9,10$, and 11 with only 560 cows.

It is evident from such a comparison as the foregoing that breeders retained more than 2,000 cows in their herds that gave them inadequate returns of registered calves.

Except in times of great demand and extreme prices it is very doubtful if much or even any profit was derived by the breeders from the 47 per cent or 2,360 cows in groups 1,2 , and 3 .

\section{Sex Ratio of Registered Calves from 10,000 Cows Calved 1908}

The numbers of cow and bull calves were taken separately from the Produce Record Cards for each of the 5,560 producing Shorthorn cows in the 10,000 cows of 1908 included in this study. These items were then checked against the total number of calves for each cow. The total number of calves produced by the 5,560 producing cows was 22,275 . Of the total 12,735 were cow calves and 9,540 were bulls. The ratio thus obtained is 1 bull to 1.33 cows.

A sex ratio for comparison was calculated from the herdbooks, January 22, 1907, when Volume 70 was opened, until April 23, 1923, when Volume 112 was closed. The registration of cows by numbers, separate and apart from numbers given to bulls, was inaugurated after the completion of the American Shorthorn herdbook, Volume 69 , closed January 21, 1907. This method of registration was continued until the completion of Volume 90, April 21, 1916. Bulls and cows were registered in the order received at the office of the association, without separation of sexes, beginning with Volume 91, opened April 22, 1916. The sex ratio was estimated by taking a 5 per cent sample from each of the Volumes, 91 to 112 inclusive. The results are summarized and presented in Tables $I V$ and $V$, and in Figure 3.

The average sex ratio for all Shorthorns as ascertained in this manner is 1 bull to 1.34 cows. It will be observed that the sex ratios for the calves from 1908 cows and for all Shorthorns registered from 1907 to 1923 are almost exactly equal, 1 bull to 1.33 cows for the calves from 1908 cows and 1 bull to 1.34 cows for all Shorthorns registered since 1907. The slight variance is clearly within the annual sex ratio variation.

In order to study the factors influencing the registration of each 
sex, Table $V$ was prepared. In this table volumes of the herdbook containing the cattle registered approximately within a given calenclar year are grouped and their registrations are considered as occurring therein. The time interval between the opening and closing of these groups of volumes is presented in days. The number of cattle registered in the various groups of volumes, divided by the time interval, is used to obtain the rate per day of registrations for each of the years 1907-1922 inclusive. The sex rate by volumes, as given in Table IV is averaged for each of the groups of volumes in Table $\mathrm{V}$ and this average is used for the average yearly ratios. The average auction price is based on yearly average auction prices of Shorthorns; Ashton (1922), Wentworth, Munnecke and Cross (1923), and Wentworth (1921). The average yearly ratio, average daily rate of registration by years, and average auction price is graphically presented in Figure 3. The number of registered cows to 100 registered bulls is used for plotting the yearly sex ratio curve.

Comparing sex ratio and price as plotted in Figure 3 it will be observed that with the exceptions of the years 1915 and 1916 the proportion of cows to bulls registered declines as price rises and rises as price falls. The exception above noted was due to the rule governing the time limit of registration. Previous to January 10, 1916, a breeder had three years in which he might register Shorthorns without payment of penalty fees. After January 10, 1916, the rule in force required registration within one year from date of birth. A penalty fee of $\$ 10.00$ was required of the owner for registration of cattle over one year old. This rule had a result of doubling registrations just previous to its being put in force. Table IV, Volume 89 and 90 shows that the registrations of bulls was not affected, but the registration of cows was nearly doubled, hence the change in ratio in favor of the covs.

The annual average daily registration is affected by prices. It will be observed that as prices rose, the number of cattle registered increased as a general rule. From 1909 to 1912 the trend of values, while on the up grade, was apparently not enough higher to increase registrations. The rise in values in 1912 and thereafter was sufficient to increase materially registrations. Continuous rising values and a change in rules as above noted, were sufficient to increase the rate and number of yearly registrations to the extent that nearly three times as many cattle were registered yearly from 1912 to 1922 , as were registered yearly from 1907 to 1912.

The sex ratio in a general way varies with the number of cattle registered. If increasing numbers of cattle are registered the pro- 
portion of cows to bulls registered tends to rise. On the other hand as registrations become fewer the proportion of cows to bulls tends downward.

Wentworth (1921) has shown that registered cattle prices rise and fall with market cattle prices in approximate ratio of three dollars for registered cattle to one dollar for market cattle.

TABLE IV.-Registration and Sex Ratio of Shorthorns from January 22, 1907, to April 23, 1923, Volumes 70-112 Inclusive.

\begin{tabular}{|c|c|c|c|c|c|c|}
\hline Vol. No. & Date & Closed & Net Cows & Net Bulls & $\begin{array}{r}\text { Ratio } \\
B \text { to C }\end{array}$ & $\begin{array}{l}\text { Total Bulls } \\
\text { and Cows }\end{array}$ \\
\hline $70^{*}$ & June & 25,1907 & 12,000 & 9,000 & $1: 1.33$ & 21,000 \\
\hline 71 & Dec. & 18, 1907 & 11,000 & 9,000 & $1: 1.22$ & 20,000 \\
\hline 72 & May & 5, 1908 & 12,000 & 9,000 & $1: 1.33$ & 21,000 \\
\hline 73 & Dec. & $1, \quad 1908$ & 12,000 & 8,000 & $1: 1.50$ & 20,000 \\
\hline 74 & Apr. & 14,1909 & 11,000 & 9,000 & $1: 1.22$ & 21,000 \\
\hline 75 & Nov. & 2,1909 & 12,000 & 8,000 & $1: 1.50$ & 20,000 \\
\hline 76 & Apr. & $20, \quad 1910$ & 11,000 & 9,000 & $1: 1.22$ & 20,000 \\
\hline 77 & Nov. & 30,1910 & 11,000 & 9,000 & $1: 1.22$ & 20,000 \\
\hline 78 & Apr. & 18,1911 & 12,000 & 8,000 & $1: 1.50$ & 20,000 \\
\hline 79 & Dec. & $28, \quad 1911$ & 11,000 & 9,000 & $1: 1.22$ & 20,000 \\
\hline 80 & June & $26, \quad 1912$ & 12,000 & 8,000 & $1: 1.50$ & 20,000 \\
\hline 81 & Jan. & 29,1913 & 11,000 & 9,000 & $1: 1.22$ & 20,000 \\
\hline 82 & May 1 & $15, \quad 1913$ & 11,000 & 9,000 & $1: 1.22$ & 20,000 \\
\hline 83 & Dec. & 25,1913 & 11,000 & 9,000 & $1: 1.22$ & 20,000 \\
\hline 84 & Apr. & 8,1914 & 12,000 & 8,000 & $1: 1.22$ & 20,000 \\
\hline 85 & Oct. & 7, 1914 & 10,000 & 10,000 & $1: 1.00$ & 20,000 \\
\hline 86 & Feb. & 10,1915 & 11,000 & 9,000 & $1: 1.22$ & 20,000 \\
\hline 87 & May & $5, \quad 1915$ & 12,000 & 8,000 & $1: 1.50$ & 20,000 \\
\hline 88 & Oct. & 27,1915 & 12,000 & 8,000 & $1: 1.50$ & 20,000 \\
\hline 89 & Feb. & 2,1916 & 19,000 & 11,000 & $1: 1.82$ & 30.000 \\
\hline 90 & Apr. & 21,1916 & 21,000 & 9,000 & $1: 2.32$ & 30,000 \\
\hline 91 & June & 2, 1916 & 16,500 & 13,500 & $1: 1.22$ & 40,000 \\
\hline 92 & Nov. & 1, 1916 & 16,300 & 13,700 & $1: 1.19$ & 40,000 \\
\hline 93 & Mar. & 4, 1917 & 16,600 & 13,400 & $1: 1.24$ & 40,000 \\
\hline 94 & July 1 & $17, \quad 1917$ & 16,600 & 13,400 & $1: 1.24$ & 40,000 \\
\hline 95 & Oct & 10,1917 & 17,200 & 12,800 & $1: 1.34$ & 40,000 \\
\hline 96 & Jan. & 10,1918 & 16,300 & 13,700 & $1: 1.19$ & 40,000 \\
\hline 97 & Apr. & 24,1918 & 17,300 & 12,700 & $1: 1.36$ & 40,000 \\
\hline 98 & Aug. & 17, 1918 & 16,700 & 13,300 & $1: 1.26$ & 40,000 \\
\hline 99 & Dec. & $5, \quad 1918$ & 15,800 & 14,200 & $1: 1.11$ & 40,000 \\
\hline 100 & Mar. & 13,1919 & 16,400 & 13,600 & $1: 1.20$ & 40,000 \\
\hline 101 & June & $4, \quad 1919$ & 15,600 & 14,400 & $1: 1.08$ & 40,000 \\
\hline 102 & Sept. & 18,1919 & 17,500 & 12,500 & $1: 1.40$ & 40,000 \\
\hline 103 & Dec. & $11, \quad 1919$ & 16,600 & 13,400 & $1: 1.24$ & 40,000 \\
\hline 104 & Mar. & 11,1920 & 17,000 & 13,000 & $1: 1.31$ & 40,000 \\
\hline 105 & May & $26, \quad 1920$ & 15,500 & 14,500 & $1: 1.07$ & 40,000 \\
\hline 106 & Sept. & 10,1920 & 16,500 & 13,500 & $1: 1.22$ & 40,000 \\
\hline 107 & Dec. & 20,1920 & 16,600 & 13,400 & $1: 1.24$ & 40,000 \\
\hline 108 & Apr. & 26,1921 & 18,600 & 11,400 & $1: 1.64$ & 40,000 \\
\hline 109 & Aug. & 19,1921 & 16,800 & 13,200 & $1: 1.27$ & 40,000 \\
\hline 110 & Mar. & 29,1922 & 29,300 & 20,700 & $1: 1.41$ & 50,000 \\
\hline 111 & Oct. & $20, \quad 1922$ & 31,500 & 18,500 & $1: 1.70$ & 50,000 \\
\hline 112 & Apr. & 23,1923 & 31,200 & 18,800 & $1: 1.65$ & 50,000 \\
\hline
\end{tabular}

** Volume 70 opened January 22, 1907. 


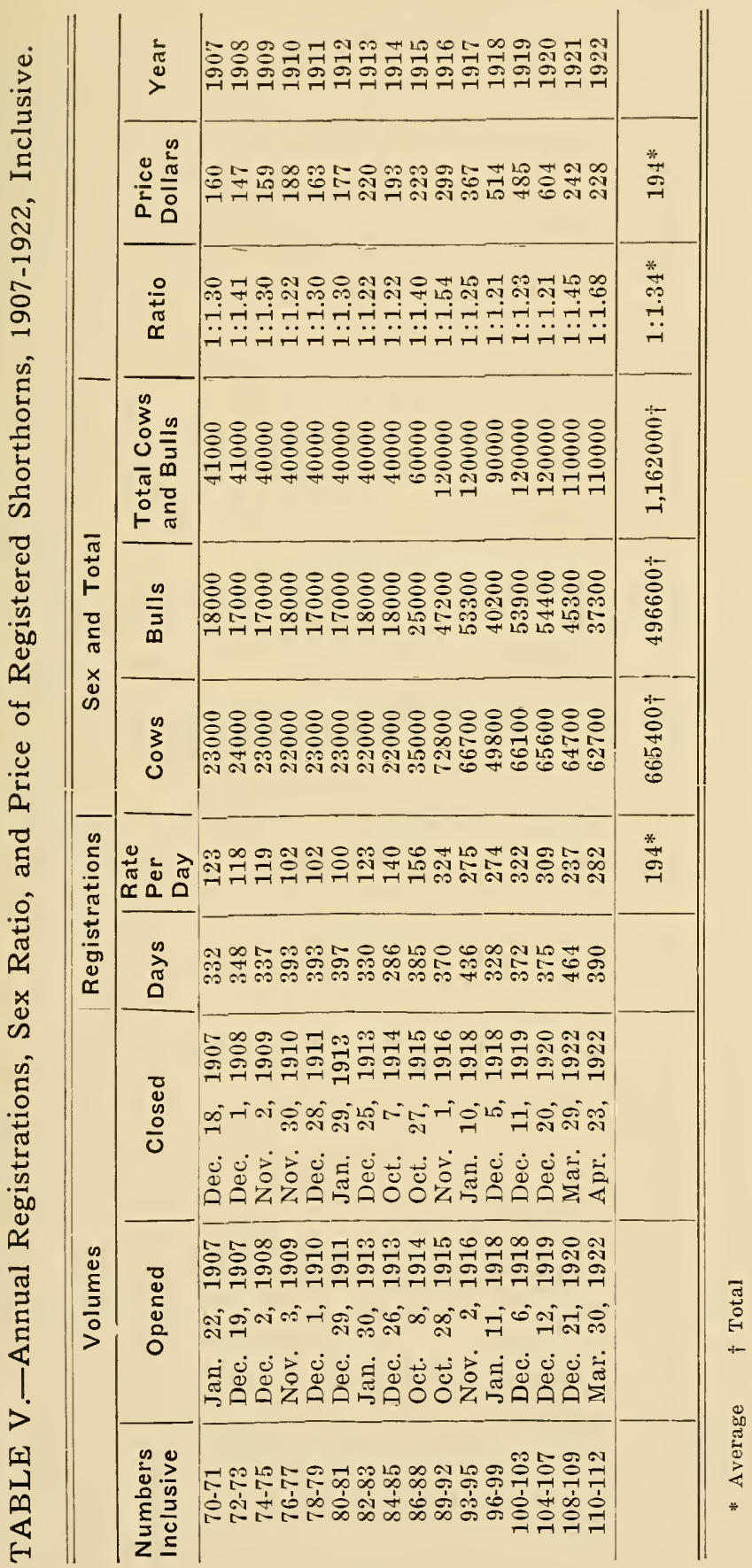




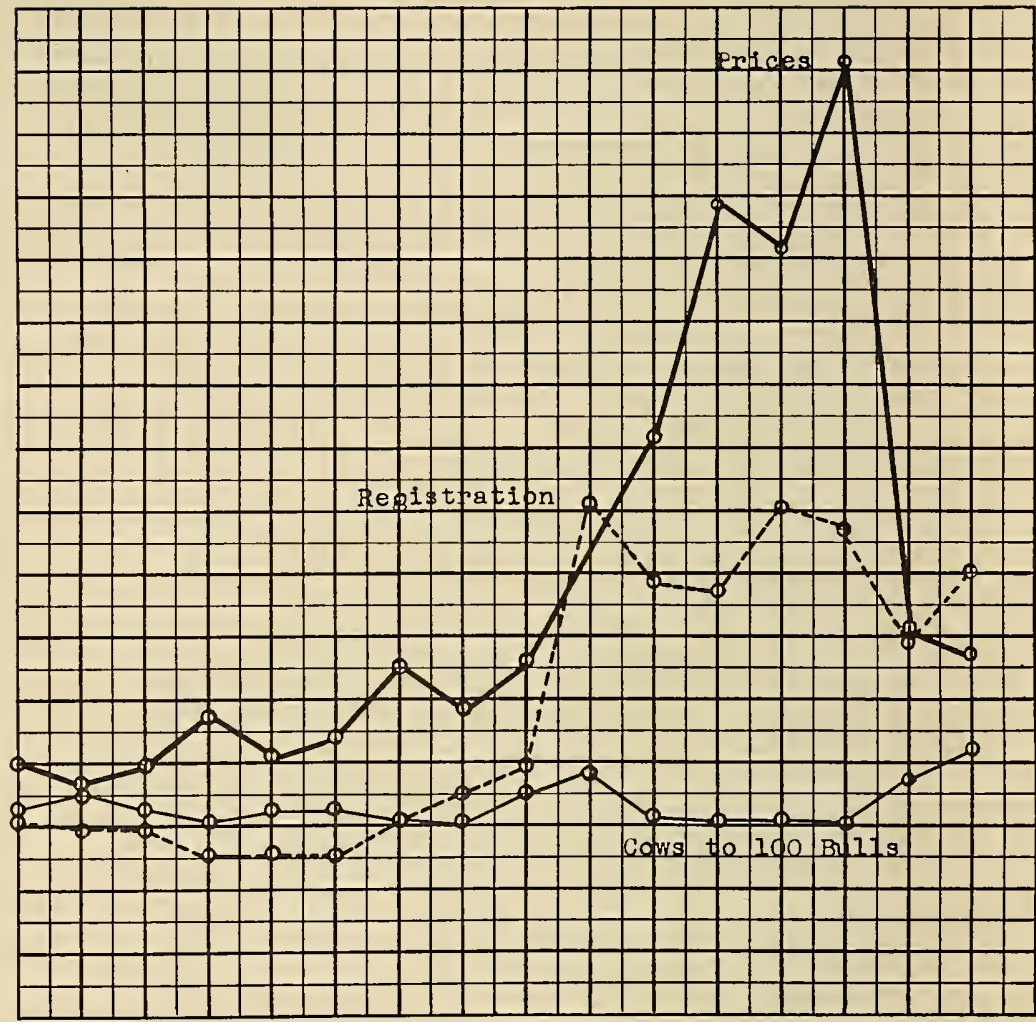

300

200

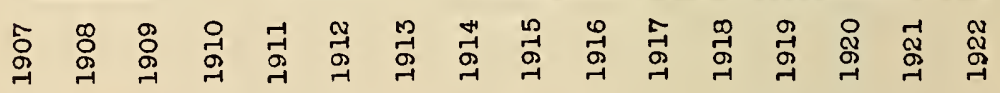

Fig. 3.-Annual Registration, Sex Ratio, and Average Price of Registered Shorthorns, 1907-1922.

This being true the variation in sex ratio may be readily explained. As prices of market cattle advance purebred prices rise, purebred bulls are in greater demand, bring higher values and that class of bulls known as "Farmers' Bulls" that is used for the production of market cattle and upon grade breeding cattle, is registered in increasing proportionate numbers to purebred females. The reverse is true when values of market cattle fall. Purebred values decline, a smaller proportionate number of the cheaper bulls is registered and sold for breeding purposes. More of the cheaper bulls under this last condition are converted into steers, or if used for breeding purposes are not recorded.

It will be observed from the chart that prices and registrations fell markedly in 1920 and that the sex ratio began to rise, while in 
1921 and 1922 prices were still downward and an increasing proportion of cows was registered, the rate of registration contrary to the normal expectancy al-u rose. J. L. Tormey (1923) states that 9,000 new owners appeare! on the records, September, 1922, to September 1923. This statement explains the increase in registration. Also it should be kept in mind that many breeders had not materially reduced the number of breeding cows in their herds and were castrating many bulls while recording approximately the normal number of heifers.

In the event of continous downward prices for Shorthorns we may reasonably expect to see many of the less desirable heifers sent to the shambles or into the hands of men who will record few if any of their offspring, while the demand for purebred bulls, though not necessarily registered, by breeders of grade cattle should expand.

With these facts in mind it seems likely that the 22,275 calves registered in the ratio of 133 cows to 100 bulls are not the entire calf crop of the 5,560 cows that produced them. If we assume that the sex ratio at birth was equal and that all the heifers were registered from these cows then it is evident that at least some 3,195 bulls were disposed of without being registered. While it is conceded here that there may have been additional numbers of each sex that may have returned the owners of these producing cows something, there is no evidence for or against any such concession on the Produce Record Cards.

\section{Last Calf Produced by 5,560 Cows}

Plumb (1904) in his "Little Sketches of Famous Cattle" recounts the records of "Old Grannie," a famous Aberdeen-Angus cow owned by Hugh Watson of Keillor, Scotland, and of "Young Mary," a Shorthorn cow imported into the United States in 1834 by Felix Renick for the Ohio Breeding and Importing Company.

"Old Grannie" lived to be thirty-five years and six months old. In her breeding life she produced twenty-five calves. The last calf produced by her was dropped when she was twenty-nine years old.

"Young Mary" also proved to be both long-lived and prolific. She is said to have been twenty-one years old at the time of her death and to have produced twenty calves, of which number sixteen were heifers and four were bulls.

The records of these two cows are of course exceptional, never- 
the-less they are interesting in that they show the possibilities of one cow for positive influence and benefit, to a breed.

The Produce Record Cards of the cows producing calves make it possible to give an accurate idea of what the probabilities of exceptional productions are for these 5,560 cows. A fair idea may be formed relative to the requirements of breeders for herd replacement. In other words, it is possible by such a study to compile what to all intents and purposes is a mortuary table for Shorthorn breeding cows.

Methods of Study.-The date of birth of the last calf produced by 3,835 of the productive cows was obtained from the Produce Record Cards. All of the records in the active file were secured and part of the records from the inactive file. An estimate based upon the results obtained by sampling the inactive file with the fifth and tenth thousand cows, or a 20 per cent sample was used to complete the records of the other 1,725 cards of producing cows.

Table VI and Figure 4 give the result of the investigations. TABLE VI.-Year of Last Calving 5,560 Cows.

\begin{tabular}{c|c|c|c|c}
\hline \hline Year & Number & $\begin{array}{c}\text { Cumulative } \\
\text { Number }\end{array}$ & Per Cent & $\begin{array}{c}\text { Cumulative } \\
\text { Per Cent }\end{array}$ \\
\hline 1910 & 270 & 270 & 4.9 & 4.9 \\
1911 & 480 & 750 & 8.6 & 13.5 \\
1912 & 465 & 1215 & 8.4 & 21.9 \\
1913 & 360 & 1575 & 6.5 & 28.4 \\
1914 & 460 & 2035 & 8.3 & 36.7 \\
1915 & 475 & 2510 & 8.5 & 45.2 \\
1916 & 540 & 3050 & 9.7 & 54.9 \\
1917 & 585 & 3635 & 10.5 & 65.4 \\
1918 & 650 & 4285 & 11.6 & 77.0 \\
1919 & 740 & 5025 & 13.3 & 90.3 \\
1920 & 420 & 5445 & 7.6 & 97.9 \\
1921 & 115 & 5560 & 2.1 & 100.0 \\
\hline \hline
\end{tabular}

The table and chart show that half of the cows had their last calf by the end of their eighth year or in 1916. With the exception of the years 1910, 1911, and 1912 the number ceasing from further production of calves tends to accelerate in a uniform degree from year to year. The numbers dropping out in 1910, 1911, and 1912 are increased by the large numbers of cows that had their first, last, and only registered calf in these three years.

A little more than three-fourths of the cows had been dropped by their breeders from the herds by 1918 , and 90 per cent have had no calves since 1919 . This data then, shows that relatively few cows are retained by breeders after they are twelve years old. 
800

700

600

500

400

300

200

100

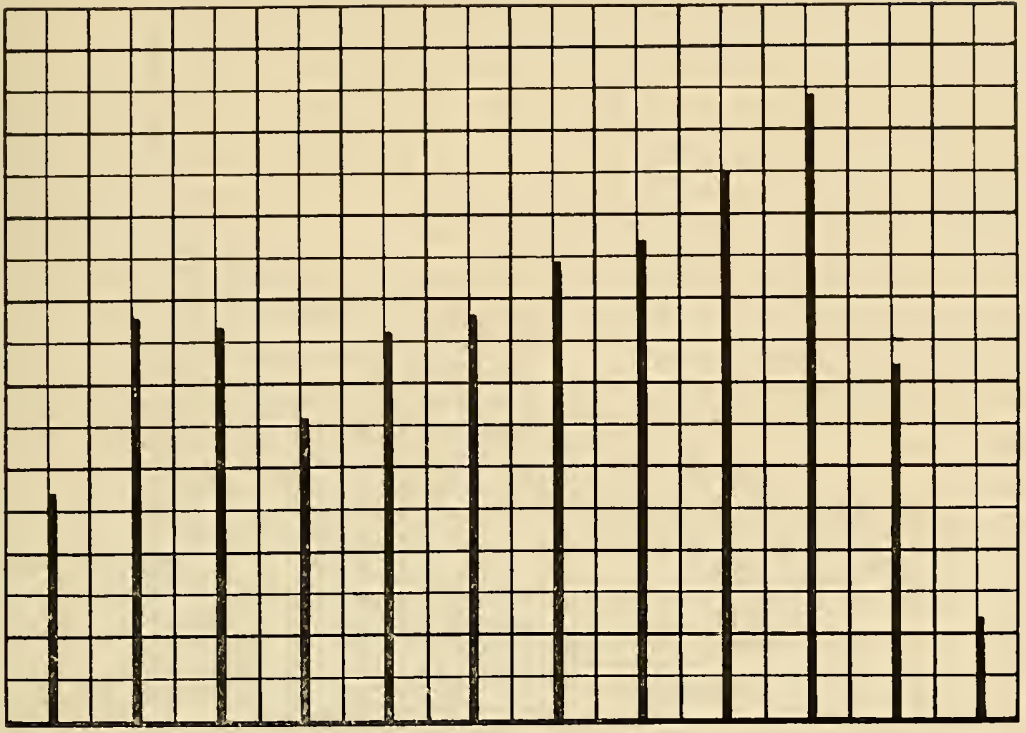

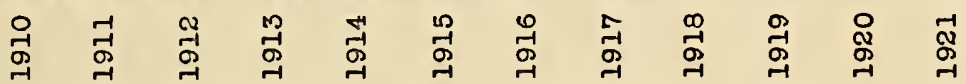

Fig. 4.-10,000 Shorthorn Cows Calved 1908; 5,560 Producing Shorthorn Cows Grouped with Reference to Last Calf.

Frequency Table VII and Figure 5 give the results obtained by assorting the cows into bi-monthly groups 1910-1921 inclusive.

TABLE VII.-Last Calf of 5,560 Producing Cows Bi-Monthly and Annually, 1910-1921.

\begin{tabular}{|c|c|c|c|c|c|c|c|}
\hline \multirow[b]{2}{*}{ Years } & \multicolumn{6}{|c|}{ MONTHS } & \multirow[b]{2}{*}{$\begin{array}{l}\text { Yearly } \\
\text { Totals }\end{array}$} \\
\hline & Jan.-Feb. & Mar.-Apr. & May-June & July-Aug. & Sept.-Oct. & Nov.-Dec. & \\
\hline 1910 & 25 & 40 & 40 & 65 & 45 & 55 & 270 \\
\hline 1911 & 65 & 140 & 85 & 60 & 45 & 85 & 480 \\
\hline 1912 & 85 & 105 & 110 & 70 & 45 & 50 & 465 \\
\hline 1913 & 65 & 70 & 95 & 55 & 20 & 55 & 360 \\
\hline 1914 & 70 & 120 & $\$ 5$ & 50 & 80 & 55 & 460 \\
\hline 1915 & 90 & 100 & 100 & 60 & 55 & 60 & 475 \\
\hline 1916 & 40 & 155 & 130 & 70 & 65 & 80 & 540 \\
\hline 1917 & 60 & 130 & 130 & 105 & 70 & 90 & 565 \\
\hline 1918 & 140 & 120 & 145 & 85 & 85 & 75 & 650 \\
\hline 1919 & 120 & 130 & 165 & 105 & 95 & 125 & 740 \\
\hline 1920 & 95 & 90 & 50 & 55 & 60 & 70 & 420 \\
\hline $\begin{array}{r}1921 \\
\end{array}$ & 60 & 30 & 10 & 5 & 5 & 5 & 115 \\
\hline $\begin{array}{l}\text { Bi-Monthly } \\
\text { Totals }\end{array}$ & 915 & 1230 & 1155 & 785 & 670 & 805 & 5560 \\
\hline
\end{tabular}

It is worthy of note that the last calf of the largest groups in each year was as a rule dropped in the spring. 


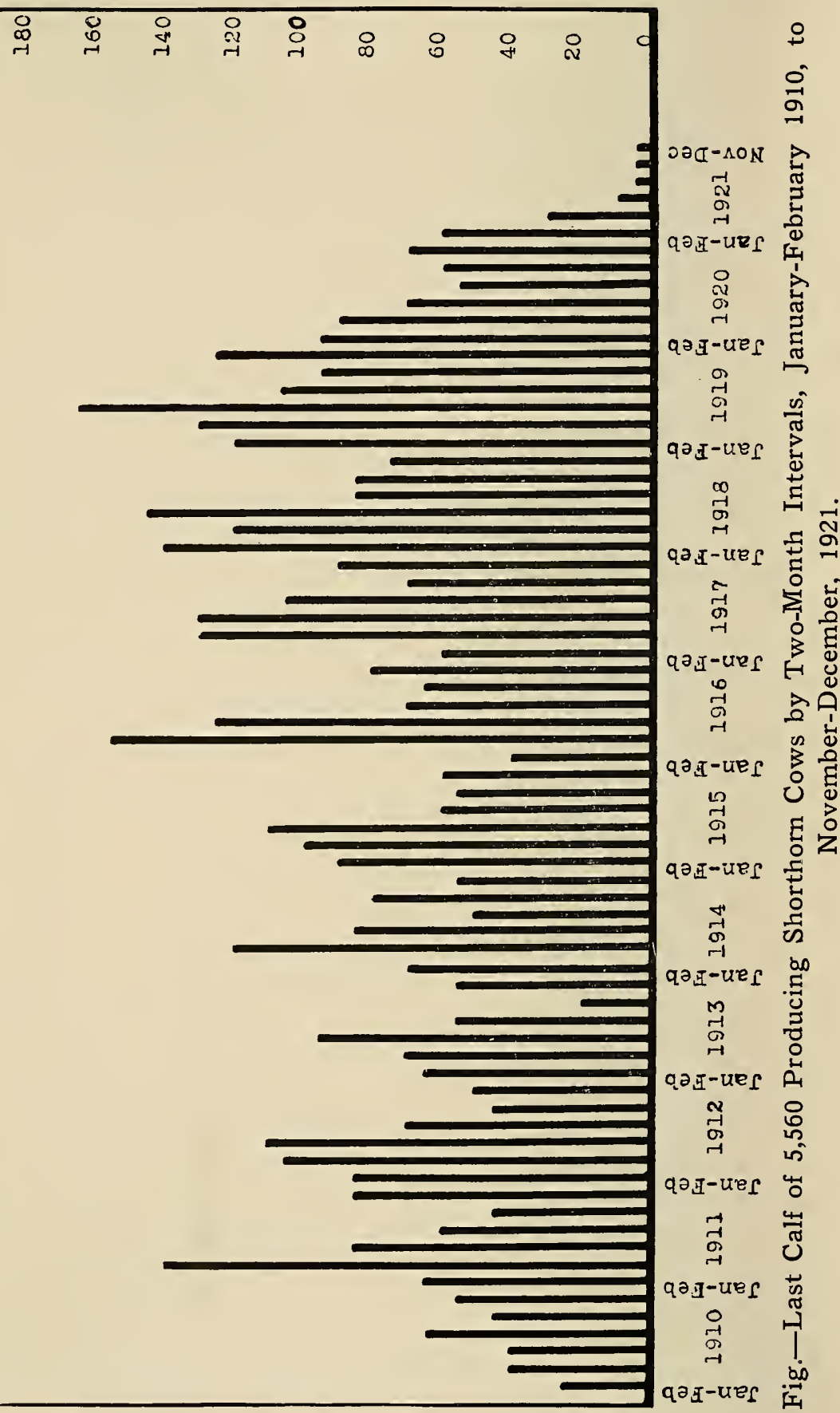




\section{Family Derivation of Exceptional Producers}

A very natural interest is aroused relative to the "family" of cows that produced nine or ten calves. Sale prices for the so-called "Scotch" and "Pure Scotch" bred cattle are ustrally enough higher than for the so-called "Scotch-topped," "English," and "plain bred" cattle to furnish a basis for the hypothesis that perhaps it was the Scotch bred cows that had the large number of registered calves. If such an idea were to be proved correct one would naturally expect to find few if any of the "English" and "plain bred" cows in the groups of cows producing a registered calf each year.

Methods of Study.-Eighty-six cows producing nine or ten calves were selected at random from the data sheets as a representative sample of these groups for study.

The pedigree of each cow selected was traced through The American Shorthorn herdbooks and Warfield's List of Imported Cows was used as far as possible to obtain their family origin. Coate's lierdbook was used to trace the imported dams not listed by Warfield and for the cows of Scotch origin.

Results of Study.-The results of the investigations are given in Tables VIII and IX.

TABLE VIII.-Family Derivation of 18 Cows Calving 10 Calves.

\section{A. From Scotch Foundation (4)}

1. Butterfly-Cruikshank

2. Victoria through Victoria 71st-Cruikshank

3. Victoria through Victoria 85 th-Cruikshank

4. Waterwitch-Cruikshank

B. From English Foundation (14)

1. Adelaide by Magnum Bonum

2. Avirilda by Norfolk

3. Irene by Sheldon

4. Matilda by Imperial

5. Medora by Horatio

6. Miss Hudson by Heremes

7. Pansy by Blaize

8. Phoeba by Prince Albert

9. Red Rose by Skipton

10. Rose of Strathallen by Allen

11. White Rose by Publicola

12. Young Mary by Jupiter

13. Young Mary by Jupiter

14. Young Mary by Jupiter 


\section{TABLE IX.-Family Derivation of 68 Cows Calving 9 Calves.}

\section{A. From Scotch Foundation (19)}

1. Beauty-Marr

2. Bonnie Bell (Duthie bred)

3. Clipper-Cruikshank

4. Duchess of Gloster (through 33rd)-Cruikshank

5. Evangeline-Duthie

6. Flora-Marr

7. Flowery-Hay

8. Golden Drop (Thessalonica)-Campbell

9. Lustre--Duke of Richmond

10. Louisa (Cruickshank bred)

11. Mina-Campbell

12. Miss Ransden-Campbell

13. Nonpariel (Through Imp. Dalmeny Nonpariel 3rd)-Cruikshank

14. Nonpariel (Through Imp. Dalmeny Nonpariel 3rd)-Cruikshank

15. Princess Royal-Duthie

16. Raspberry-Marr

17. Rosemary-Sheppard

18. Secret-Cruikshank

19. Victoria-Cruikshank

B. From English Foundation (49)

1. Amelia by Plato

2. Amelia by Louisville to Beauty of Kentucky 17's-Sanders Importation

3. Arabella by North Star-Wetherell

4. Beauty by Snowball

5. Beauty by Snowball

6. Belina by Barmpton

7. Bright Eyes to Imp. Beauty by Devaugh-J. Whittaker

8. Cambridge Rose to Bates' Cambridge Rose by Belvidere

9. Clay Cow by Don Juan Kentucky 17's-Sanders Importation

10. Constance by Bridegroom-Mr. Fawkes

Carolina by Dashwood-Dunn Importation

12. Craggs to Craggs by 2nd Hubback-Bates

13. Duchess to Duchess of Athol by 2nd Duke of Oxford-Bates.

14. Durham Cow to Kentucky 17's-Sanders Importation

15. Eliza to Eliza of Sherwood-Mason of Chilton

16. Fanny Ellsler to Kentucky 17's-Sanders Importation

17. Filbert to Filbert by 2nd Cleveland Lad

18. Flora by Lafon's Son of Comet

19. Flora by Young Albion

20. Frantic by Duke of York

21. Ianthe by Barforth

22. Ianthe by Barforth

23. Jessey by Plenipo

24. Josephine by Norfolk-J. Whittaker

25. Josephine by Norfolk-J. Whittaker

26. Josephine by Norfolk-J. Whittaker

27. Lucretia-H. Clay Importation

28. Mandare by Richmond

29. Margaret by Snowball

30. Matilda by Imperial

31. Moss Rose to Moss Rose by Priam-R. Booth

32. Mrs. Motte by Adam

33. Mrs. Motte by Adam

34. Mrs. Motte by Adam

35. Pink by Reformer 
36. Princess by Son of Lancastel

37. Princess by Wynward

38. Red Rose by Ernesty

39. Rose of Sharon by Belvidere

40. Rose of Sharon by Belvidere

41. Rosemary by Flash

42. Sylvia by Luck's All

43. Virginia by Mowhawk

44. White Rose by Publicola-Dunn Importation

45. White Rose by Publicola-Dunn Importation

46. White Rose by Publicola-Dunn Importation

47. Young Mary by Jupiter

48. Young Phyllis by Fairfax

49. Young Phyllis by Fairfax

Tables VIII and IX show that twenty-three of the cows are of Scotch origin and sixty-three are of English origin.

The twenty-three Scotch cows are derived from twenty families. There were two Nonpareils and three Victoria's. The Nonpareils trace through the same imported dam but the Victoria's do not. It is worthy of note that Cruickshank bred both families.

The sixty-three cows of English derivation trace through but forty-six imported dams. The families appearing more than once in the sixty-three cows are listed in Table X.

TABLE X.-Imported Dams Represented by Two or More Cows.

Beauty by Snowball
Ianthe by Barforth
Josephine by Norfolk
Matilda by Imperial
Mrs. Motte by Adam
Rose of Sharon by Belvidere
White Rose by Publicola
Young Mary by Jupiter
Young Phyllis by Fairfax

These data show that there are only sixty-six families represented by the eighty-six cows studied. There is no evidence in this data to support the hypothesis that Scotch-bred calves are all registered and because of less popularity and lower prices only the best Scotch-topped calves are retained.

It will be observed that many of the "English" bred cows are from dams imported at an early period. In many instances, twenty cr more crosses have been made on the family since the time of importation. According to Black* of the Bureau of Animal Industry only one Shorthorn cow was imported in 1908 and she does not appear in this grone. The eighty-six cows are owned in seventeen states and no two of them by one owner.

* Black, W. H. Letter to author, July 19, 1922. (Information based on reports made in accordance with Bureau of Animai Industry, order No. 79 , requiring all cattle imported into the United States to be tested for tuberculosis). 


\section{Twin Cows Registered in 5,000 Shorthorn Cows}

Twin cows calved in the first 5,000 cows registered as calved in inos were especially noted for study. A total of forty-nine cows was registered as one of the twins. Of the forty-nine cows so regislered thirty-two were twin sisters. The remaining seventeen were registered as one of twins without reference to the sex of the other twin that was not found. The forty-nine cows represent thirty-three twin births in 5,000 cows.

The breedins record of the seventeen cows registered as one of the twins, the other twin not located, is presented in Table XI.

TABLE XI.-Breeding Record of Twins (One of a Pair, the Other Not Found).

\begin{tabular}{|c|c|c|c|c|c|c|}
\hline Reg. No. & Name & First Calf & Last Calf & Bulls & Cows & Total \\
\hline 34092 & Clara & No Produce & & & & \\
\hline 40444 & Orange Queen & No Produce & & & & \\
\hline 47102 & Proud Lady & No Produce & & & & \\
\hline 47822 & Graceful Lady & No Produce & & & & \\
\hline 49447 & Rosa & No Produce & & & & \\
\hline 50937 & Ruth & No Produce & & & & \\
\hline 43155 & Repeat & No Produce & & & & \\
\hline 54707 & Caprice & No Produce & & & & \\
\hline 55146 & Arah Wanna & No Produce & & & & \\
\hline 56434 & Orange Blossom & No Produce & & & & \\
\hline 56789 & Gold Bess & No Produce & & & & \\
\hline 56906 & Princess Laporte & No Produce & & & & \\
\hline 59898 & Lavender Sultana & No Produce & & & & \\
\hline 60173 & Beauty Frangr'nt & No Produce & & & & \\
\hline 60221 & Missie 160th & Apr. 1909 & Jan. 1914 & 3 & 2 & 5 \\
\hline 62141 & Henrietta & Dec. 1913 & May 1915 & 1 & 1 & 2 \\
\hline \multirow[t]{2}{*}{63190} & Scotch Lassie & Feb. 1913 & Tuly 1910 & 2 & 1 & 3 \\
\hline & & & Totals & 6 & 4 & 10 \\
\hline
\end{tabular}

Of the twins where but one was found fourteen had no produce and three did produce. It is highly probable that some of the fourteen were twinned with a bull. Data could not be secured covering that point.

The record for the twins where each cow of the pair was found registered is comparable to the records of the 10,000 cows discussed previous to this study. Fourteen of the thirty-two did not produce. The percentage of productive twins to non-productive twins is 56.25 to 43.75 . The sex ratio is 1 bull to 1.2 cows. 
TABLE XII.-Breeding Record of Twins (Each of a Pair Registered).

\begin{tabular}{|c|c|c|c|c|c|c|}
\hline Reg. No. & Name & First Calf & Last Calf & Bulls & Cows & Total \\
\hline 41771 & Princess Belle & July 1912 & July 1912 & & 1 & 1 \\
\hline 41772 & Princess Bonnie & Mar. 1912 & Mar. 1912 & & 1 & 1 \\
\hline $\begin{array}{l}42241 \\
42243 \\
\end{array}$ & $\begin{array}{l}\text { Lena } \\
\text { Rena }\end{array}$ & $\begin{array}{l}\text { Jan. } 1912 \\
\text { No produce }\end{array}$ & July 1917 & 2 & 3 & 5 \\
\hline 42290 & Mabel & Oct. 1910 & Apr. 1920 & 6 & 3 & $\begin{array}{l}9 \\
5\end{array}$ \\
\hline 46713 & Roany 8th & Apr. 1912 & June 1914 & 1 & 1 & $\frac{5}{2}$ \\
\hline 46714 & Roany 9th & Apr. 1911 & Apr. 1912 & 1 & 1 & 2 \\
\hline 47703 & Rena Rachel & Aug. 1911 & Jan. 1914 & 1 & 2 & 3 \\
\hline 47704 & Lena Rachel & Aug. 1911 & July 1913 & 1 & 1 & 2 \\
\hline $\begin{array}{l}49770 \\
49771\end{array}$ & $\begin{array}{l}\text { Duplicate } \\
\text { Kate }\end{array}$ & $\begin{array}{l}\text { No produce } \\
\text { Oct. } 1911\end{array}$ & Oct. 1911 & & 1 & 1 \\
\hline $\begin{array}{l}51211 \\
51212\end{array}$ & $\begin{array}{l}7 \text { Fairv'w Evelyn } \\
8 \text { Fairv'w Evelyn }\end{array}$ & $\begin{array}{l}\text { No produce } \\
\text { No produce }\end{array}$ & & & & \\
\hline $\begin{array}{l}53339 \\
53353\end{array}$ & $\begin{array}{l}\text { Carnation } \\
\text { Orchid }\end{array}$ & $\begin{array}{l}\text { May } 1912 \\
\text { July } 1910\end{array}$ & Apr. 1917 & 2 & $\begin{array}{l}2 \\
1\end{array}$ & $\begin{array}{l}4 \\
1\end{array}$ \\
\hline $\begin{array}{l}55039 \\
55040\end{array}$ & $\begin{array}{l}\text { Twinkle } \\
\text { Twilight }\end{array}$ & $\begin{array}{l}\text { No produce } \\
\text { No produce }\end{array}$ & & & & \\
\hline $\begin{array}{l}56039 \\
56040\end{array}$ & $\begin{array}{l}\text { 28th Beechwood } \\
\text { Duchess } \\
\text { 29th Beechwood } \\
\text { Duchess }\end{array}$ & $\begin{array}{l}\text { Feb. } 1910 \\
\text { No produce }\end{array}$ & July 1917 & 3 & 2 & 5 \\
\hline $\begin{array}{l}59925 \\
59926\end{array}$ & $\begin{array}{lll}\text { Lady } & \text { Bell } & \text { 8th } \\
\text { Lady } & \text { Bell } & 9 \text { th }\end{array}$ & $\begin{array}{l}\text { Sept. } 1911 \\
\text { No produce }\end{array}$ & Aug 1913 & 1 & 2 & 3 \\
\hline $\begin{array}{l}59940 \\
59941\end{array}$ & $\begin{array}{l}\text { Bess } \\
\text { Bonnie }\end{array}$ & $\begin{array}{l}\text { No produce } \\
\text { No produce }\end{array}$ & & & & \\
\hline $\begin{array}{l}59964 \\
59969\end{array}$ & $\begin{array}{c}\text { Philopena 6th } \\
\text { Star Philopena } \\
5 \text { th }\end{array}$ & $\begin{array}{l}\text { Sept. } 1911 \\
\text { June } 1910\end{array}$ & $\begin{array}{l}\text { Dec. } 1916 \\
\text { May } 1918\end{array}$ & $\begin{array}{l}3 \\
5\end{array}$ & $\begin{array}{l}3 \\
2\end{array}$ & $\begin{array}{l}6 \\
7\end{array}$ \\
\hline $\begin{array}{l}62071 \\
62072\end{array}$ & $\begin{array}{l}\text { Virginia } \\
\text { Princess } 4 \text { th } \\
\text { Virginia } \\
\text { Princess } 5 \text { th }\end{array}$ & $\begin{array}{l}\text { July } 1914 \\
\text { July } 1911\end{array}$ & $\begin{array}{ll}\text { July } & 1914 \\
\text { Sept. } & 1919\end{array}$ & 2 & 6 & 1 \\
\hline $\begin{array}{l}64333 \\
64334 \\
\end{array}$ & $\begin{array}{l}\text { Fossie } \\
\text { Josie }\end{array}$ & $\begin{array}{l}\text { No produce } \\
\text { No produce }\end{array}$ & & & & \\
\hline \multirow[t]{2}{*}{64492} & $\begin{array}{l}\text { Lady Barrington } \\
\text { 4th } \\
\text { Lady Barrington } \\
5 \text { th }\end{array}$ & $\begin{array}{l}\text { No produce } \\
\text { No produce }\end{array}$ & & & & \\
\hline & & & Totals & 30 & 36 & 66 \\
\hline
\end{tabular}

TABLE XIII.-Calves Per Cow of Twin Sisters.

\begin{tabular}{l|l|l|l|l|l|l|l|l|l||c}
\hline Calves per Cow & 1 & 2 & 3 & 4 & 5 & 6 & 7 & 8 & 9 & Total Cows \\
\hline Cows Calving & 5 & 3 & 2 & 1 & 3 & 1 & 1 & 1 & 1 & 18 \\
\hline
\end{tabular}

The calves per cow for the eighteen producing cows, though but two-tenths of one per cent of the whole group studied exhibit the same tendency as the whole group for a large group of cows to calve 
a small number of calves and a small group of cows to calve a large number of calves.

In no case was a twin cow found that produced twin calves.

\section{Summary}

1.-An examination of the Produce Record Cards of 10,000 registered Shorthorn cows calved in 1908 shows that 5,560 cows produced one or more calves to July 1922 and that 4,440 cows were without registered produce.

2.-A study of the records of the 5,560 cows with registered produce shows that approximately half of the cows had less than four calves, the average number of "calves per cow" determined for the whole group. The total number of calves was 22,275 .

3.-Further study of the 5,560 cows indicates that the cows calving $4,5,6$, and 7 calves are the cows upon which the breed is chiefly dependent for the maintenance of its population.

4.-Cows calving 1,2 , and 3 calves when compared with groups of cows calving $8,9,10$, and 11 calves are 47.1 per cent of the whole producing group as compared with 10.6 per cent of the last mentioned group. The 2,630 cows in groups 1,2 , and 3 produced 4,730 calves to July, 1922, while 560 cows in groups $8,9,10$, and 11 prodituced 5,005 calves.

5.- The sex ratio of the registered calves produced by the 5,560 cows was determined to be 133 cows to 100 bulls. The sex ratio of Shorthorns registered from January 22, 1907, to April 23, 1923, was also determined and was found to average 134 cows to 100 bulls.

6.-A study of the faclors affecting the ratio of the sexes registered each year, 1907 to 1922 inclusive, shows that prices affected in a general way the total number and the sex of Shorthorns registered. In an era of high prices a larger number of bulls is registered, narrowing the ratio between bulls and cows. In an era of low prices a smaller number of bulls is registered thus making a wider sex ratio.

7.- The data show that 90.3 per cent of the cows have not calved since 1919 and that 97.9 per cent have not calved since 1920. This data indicates that, as a rule, Shorthorn breeders do not retain breeding cows in their herds after they are twelve years old.

8.-Forty-nine cows in the first 5,000 cows selected for study 
were registered as une of a pair of twins. In the forty-nine cows, sixteen pairs of twin sisters were found. The remaining seventeen were registered as one of wins withont reference to the sex of the other twin. Where only one of a pair was found three of the serenteen indicated twins produced registered calves and the other fourteen dicl not calve registered calves. Of the sixteen pairs of twin sisters each cow of seren pairs and one cow of five pairs produced calves while neither cow of four pairs produced calves. None of the twins were credited with the production of twins. Nor was there any indication that twins are more prolific in the production of registered calves than are cattle not calved as twins.

9.-A study of the tamily derivation of eighty-six cows calving nine or ten calyes, an approximate average of a calf each year, furnishes clata that tends to show that certain families among the earliest importations are prolific and widely dispersed and that (judging by the fact that their calyes are being registered) there is a market for their produce.

10.-From a study of the pedigrees of eighty-six cows it is evident that the so-called "English" and "Scotch-topped" cattle are much more numerous than the so-called "Straight or Pure Scotch."

\section{SEASONAL BIRTH OF SHORTHORN COWS}

\section{Historical}

New and inexperienced breeders frequently seek advice relative to the most desirable season to have Shorthorn cows drop their calves. Practical breeders in answering such queries, as a rule, recommend the spring season. March, April, and May, as the best season and annong other reasons given for such choice, name this season as the "natural" time for having calves diropped.

Ross (1922) in reply to such a question says, "It has been our common practice to have as many calves as possible come in January and September on account of the show season. Although I do not approve of these dates otherwise, as it is more natural to have the young come in the spring"

Numford (1920) in disctissing the breeding season makes the statement: "Among the clomestic animals the generative functions are niore active in the spring season. This is true of the horse, cow, anel pig. Sheep breed 11101 
Marshall (1322), who has made an extensive study of sheep claims there is a wicle variation in the breeding season of sheep, as is well knowin by sheep breeders, and in further discussion of the oestrous cycle of ungulates cites the work of several investigators relative to the variable breeding season of cattle. Heape is quoted by him as saying, "Wild cattle in captivity are capable of reproduction at any time during the year, but, due to an observed limited ralving season among similar animals in the wild state, the sexual periods are restricted." Raciborsky is quoted by Marshall relative to coitus, as saying, "In the more domestic types of cattle the cows receive the bull more frequently than the wilder breeds." Wallace is credited with the statement that cows usually seek the bull four or five weeks after calving, while Short is quoted as saying that in India this does not occur until after six to nine months. Actual breeding practice has demonstrated that cows may be bred to calve throughout the year, but whether all cows will do so is unproved. It may or may not be true that there is a hereditary tendency for cattle to calve in the spring; in any event it seems certain that environmental conditions for spring calving are thought to be more favorable by many breeders and students.

Warfield (1889) says, "Late fall and early winter calves cannot compete with those calved in the spring." Ross (26) thirty-five years later supports this view by saying, "Calves that come in March and April do better than fall and winter calves."

McDonald and Sinclair (1909) state that Shorthorns in Aberdeenshire are bred to calve from September to May but that February, March, and April are the months preferred. For Aberdeen-Angus the replies of numerous breeders to these writers show that December, January, February, and March are preferred, April and May being considered a little late. Hereford breeders in England prefer February, March, April, and May. The method of feeding, appearance of grass, and date for computing age for show classificationJanuary 1 , are given, by them, as the reasons for these preferences by Scotch and English breeders.

\section{Housman (1900) is in agreement with McDonald and Sinclair.}

Renick (1900), in replying to the question of proper age to breed Shorthorn heifers names the specific age of twenty months as the minimum and adds that if by waiting a few months before breeding and still have the heifer calve in the spring, the breeder will profit i) the delay. 
Potter (1921) states, "Range cattle are bred to calve in the spring and early summer, and breeders do not desire calves dropped as late as July and Angust. Fall calves in the ordinary range herd are considered expensive and unsatisfactory to produce." In the case of purebred cattle he states, "Mlost breeders, with proper feed and equipment, prefer fall calves. The breeders claim the bulls are ready for service six months before calves dropped in the spring." In this instance spring calves are two years old while fall calves are eighteen monthswhen turned with the range herds. On the other hand he states, "The chief objection to fall calves is the difficulty experienced liy breeders in securing pregnancy. The cows are harder to breed for fall calves, even under favorable conditions, than for spring."

Tomliave, Severson, and Cochel (1918) conclude in a study made with Shorthorn and Angus cows for raising beef cattle that fall calves are raised at less cost than spring calves. They claim that the difference in cost is due to fall calves requiring no extra winter feed. However, they state that spring calves from Shorthorn cows were 10.91 pounds heavier at birth, and from Aberdeen-Angus ten pounds heavier than fall calves.

Shaw (1909) states that the season of the year at which calves will be born may be partly regulated by the owner but such regulation is not entirely under his control. He summarizes the advantages and ciisadvanlages. Under advantages of fall calves he claims the grower has more time to care for the calves. The calves may be weaned in the spring without danger of checking the growth due to the cold weather and dry feed, conditions under which spring calves must be weaned. Fall calves are old enough their second winter to maintain their growth on cheaper roughages than are spring calves their first winter. That the dams of fall calves increase in milk flow when turned on pasture in the spring while cows that calve in the spring begin to dry up in the autumn, with a result of furnishing the fall calf with more milk, and the spring calf with less, when they most need an increased supply of milk. That fall calves are ready for market at a more suitable age as finished beef than are spring calves.

Under certain conditions Shaw does not believe fall calves practicable. The exceptions noted are range breeding, where the cow and calf are exposed, and large farms where dry feed only is used for wintering, and in climates without frost where pastures have lost their succulence.

Ray (1917) in discussing the advantages and disadvantages of 
fall and spring calves for baby beef points out that more shelter and feed are required for the dams of fall calves.

The American Shorthorn Breeders' Association (1924) in announcing the new show classification for 1924 shows point out that the old dates for show classification led shownen to try to have calves dropped as soon after September 1 and January 1 as possible, and led to having many calves in the fall, the least economical time of the year. They contend that spring calves can be more cheaply produced, as milk is cheaper in the spring and summer, pasture for the cows is cheaper than winter feeds, and coming at the nautral time of the year the calves are more thrifty and develop much better. They claim a development, in many cases, of impairment of breeding ability on the part of cows calving in the fall. It is worthy of note that the 1924 classification has been adopted by other beef breeding assnciations.

Methods.-This study is an attempt to furnish definite figures relative to the season the majority of practical breeders of Shorthorns have their cows drop calves. The 10,000 cows included in this study were separated into twelve groups corresponding to the months of the year, January to December inclusive, 1908. Such a division represents the practice of breeders for that year, for the 10,000 cows are approximately one-half of the number registered in that year.

Results.-The result of the foregoing division is presented in Table XIV and Figure 6.

TABLE XIV.-Birth of Shorthorn Cows by Months (10,000 Cows Calved 1908).

\begin{tabular}{l|r|r|r|r}
\hline \hline Month & Number & $\begin{array}{c}\text { Cumulative } \\
\text { Number }\end{array}$ & Per Cent & $\begin{array}{c}\text { Cumulative } \\
\text { Per Cent }\end{array}$ \\
\hline Jan. & 936 & 936 & 9.36 & 9.36 \\
Feb. & 855 & 1791 & 8.55 & 17.91 \\
Mar. & 1246 & 3037 & 12.46 & 30.37 \\
Apr. & 1400 & 4437 & 14.00 & 44.37 \\
May & 1313 & 5750 & 13.13 & 57.50 \\
June & 969 & 6719 & 9.69 & 67.19 \\
July & 711 & 7430 & 7.11 & 74.30 \\
Aug. & 527 & 7957 & 5.27 & 79.57 \\
Sept. & 665 & 8622 & 6.65 & 86.22 \\
Oct. & 519 & 9141 & 5.19 & 91.41 \\
Nov. & 400 & 9541 & 4.00 & 95.41 \\
Dec. & 459 & $\mathbf{1 0 , 0 0 0}$ & 4.59 & $\mathbf{1 0 0 . 0 0}$ \\
\hline \hline
\end{tabular}

From Table XIV it is evident that there is.a decided preference for spring calves. Calves dropped January to June inclusive are 
67.19 per cent as compared with 32.81 per cent dropped July to December inclusive. The ratio of calves dropped in the first half of the year to those dropped in the last half is slightly greater than two to one. Approximately half the calves, 49.28 per cent were dropped in the four months, March, April, May, and June.

The preference for spring and summer calves as against calves dropped in the last months of the year is even more emphatic if January to August inclusive is compared with September to December inclusive. Here the difference is approximately four to one in faror of the earlier two-thirds of the year. This difference perhaps would be greater if it were not for the show classification existing from 1902 to 1923 that divided calves and yearlings into "Juniors" and "Seniors." A "Junior" was dropped January 1 to August 31 incilusive, the year shown for the calf, and the year previous to being shown for the yearling. The "Senior" calf was dropped September 1 to December 31 the year previous to being shown and the "Senior" yearling, two years previous.

The effect of the show classification may be observed from Figure 6 , where the monthly birth rates are graphically represented.

It will be observed from the chart that there were twice as many calves dropped in January as in December and nearly one per cent more than in February. This increase in rate and in actual numbers is due to an effort on the part of breeders to have their "Innior" calves as early as possible for fall shows. The calves having greater growth and development due to age, other things being equal, have an advantage over younger animals in the same ciass.

The same explanation as offered in the preceeding paragraph applies to the rise of the curve for September. Here the percentage gain for September is approximately one and a half per cent, when compared with August and October.

Since this study was inaugurated "Juniors" and "Seniors" have been eliminated and a new classification (A. S. B. A. 1924) substituted, therefore, it is not possible to make an exact prediction of the effect of the new classification as regards the season in which Shorthorn calves are dropped. However, from a study of the new classification it seems very probable that the January ratio will not be changed materially. The same may be said of April. It seems reasonable to expect a slight increase in the calves dropped in July and October. It is certain that the percentage of calves dropped in Sep-

*February had 29 days in 1908. When calculated as calves per day for each month the January rate is 30.19 against 29.43 for February. 
tember will be lowered since there will be no benefit derived by showmen from having calves dropped in this month and there will be advantages in having calves dropped January, April, July, and October. These are the months specified as the basis of division in the new classification for the bull sections $4,5,6$, and 7 , and for cow sections 15,16 , and 17 .

The Bureau of Crop Estimates, United States Department of Agriculture, (1922) conducted an investigation to ascertain the monthly birth ratios of cattle, hogs and sheep. All classes of cattle are included in the estimate, grade and pure bred, dairy and beef cattle. The result of this investigation is compared with the Shorthorn cows of 1908 in terms of per cent in Table XV.

TABLE XV.-Birth of Shorthorns and All Cattle by Months (Shorthorns of 1908-All Cattle 1913).

\begin{tabular}{l|c|c|c|c}
\hline Month & $\begin{array}{c}\text { Per Cent of } \\
\text { Shorthorns }\end{array}$ & $\begin{array}{c}\text { Per Cent of } \\
\text { All Cattle }\end{array}$ & $\begin{array}{c}\text { Cumuative } \\
\text { Per Cent } \\
\text { Shorthorns }\end{array}$ & $\begin{array}{c}\text { Cumuative } \\
\text { Per Cent } \\
\text { All Cattle }\end{array}$ \\
\hline Jan. & 9.36 & 4.90 & 9.36 & 4.90 \\
Feb. & 8.55 & 7.20 & 17.91 & 12.10 \\
Mar. & 12.46 & 14.60 & 30.37 & 26.70 \\
Apr. & 14.00 & 19.00 & 44.37 & 45.70 \\
May & 13.13 & 16.00 & 57.50 & 61.70 \\
June & 9.69 & 8.80 & 67.19 & 70.50 \\
July & 7.11 & 4.60 & 74.30 & 75.10 \\
Aug. & 5.27 & 4.00 & 79.57 & 79.10 \\
Sept. & 6.65 & 6.20 & 86.22 & 85.30 \\
Oct. & 5.18 & 6.10 & 91.41 & 91.40 \\
Nov. & 4.00 & 4.90 & 95.41 & 96.30 \\
Dec. & 4.59 & 3.70 & 100.00 & 100.00 \\
\hline \hline
\end{tabular}

The data relative to the per cent calved each month is used to plot the curves in Figure 7 . This chart shows that the spring months are preferred not only by Shorthorn breeders but by cattle breeders in general. It will be further noted that while the percentages calved in January differ markedly for Shorthorns and for all cattle, the percentage of Shorthorns being nearly double that of all cattle, that the rate of calving in January in all cattle exceeds the December rate by approximately one per cent, or more than enough to account for cows of all breeds bred to produce show calves.

The influence of range bred cattle is responsible in some degree for the very marked preference of breeders of all cattle in having 49.6 per cent of the calves dropped in March, April, and May. It is not contended that range bred cattle are the sole cause. The September rate for Shorthorns and all cattle indicate the effect of cows 
lred for show calves. It is worthy of note, however, that many purebred dairy breeders have their cows drop fall calves claiming an in-

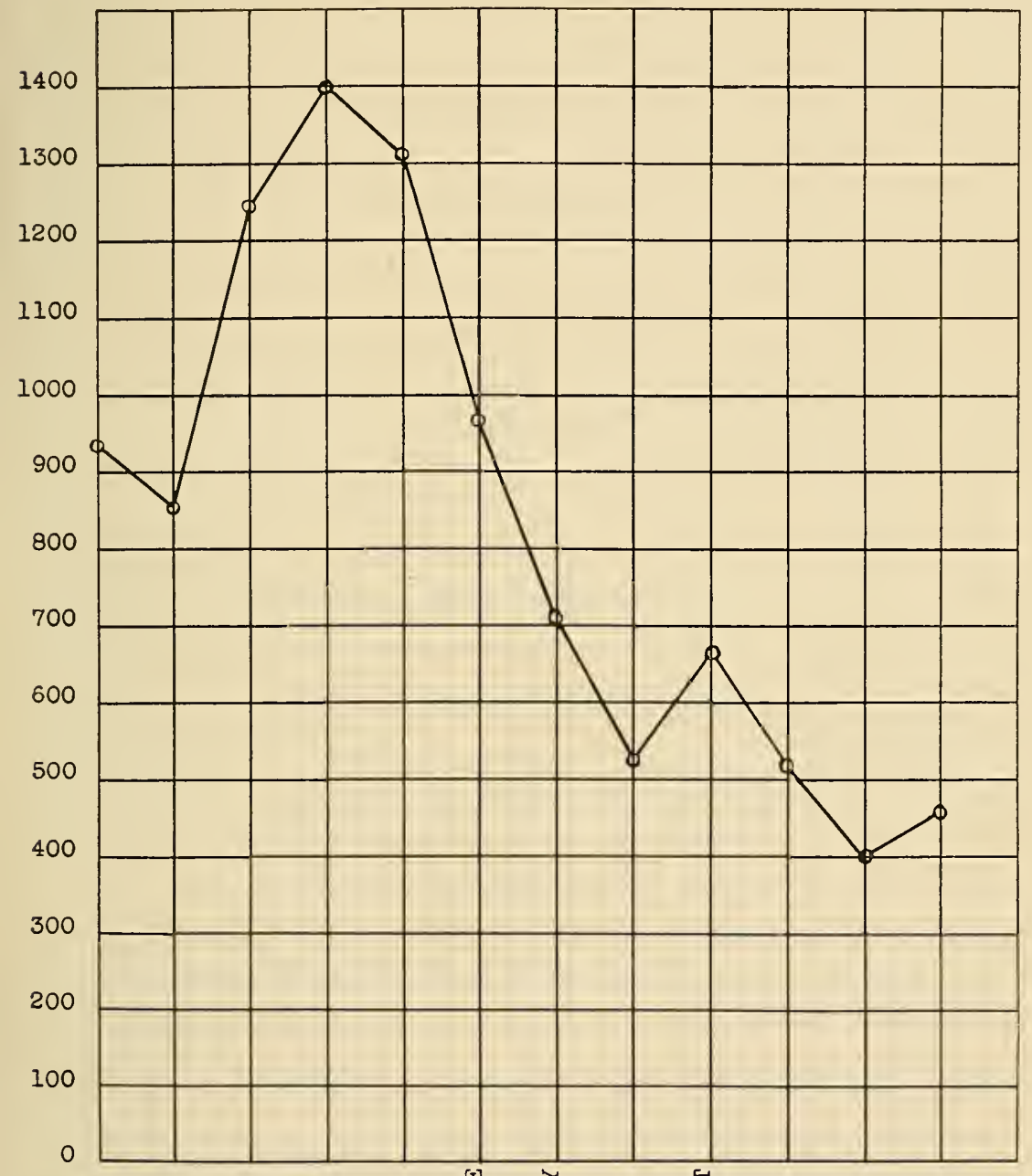

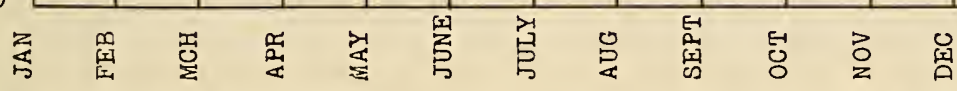

Fig. 6.-10,000 Shorthorn Cows Calved 1908, Showing Number Calved Each Month.

crease of twenty-five per cent in milk production by such practice.* Such practice would account for the sustained rise in the curve of all cattle through October.

It appears from this date that the advice often given new breed-

* Information from a chart prepared by B. A. I, Dairy Division. 
ers, to have calves dropped in the spring conforms to the general practice of the breeders of Shorthorns. Any departure from this

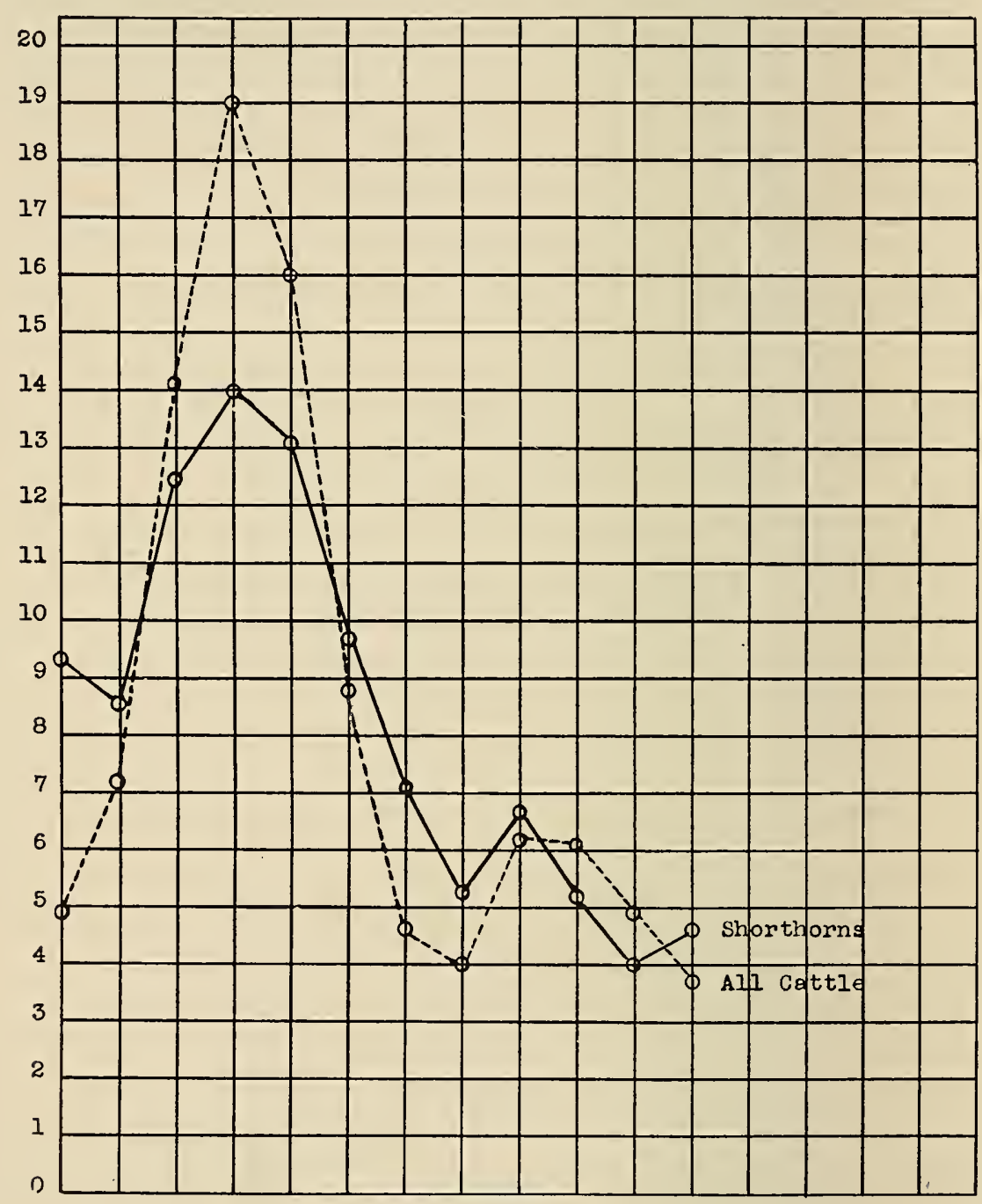

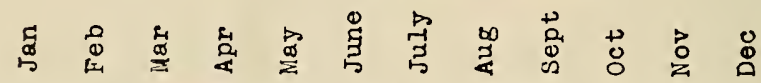

Fig. 7.-Percentage Distribution of Births of Shorthorns and of All Cattle by Months; Shorthorns of 1908 and All Cattle of 1913.

general practice can only be justified by special conditions experienced by the few rather than the many breeders. 


\section{Summary}

1.-A study of the seasonal birth of 10,000 Shorthorns calved in 1908 shows that the general practice of Shorthorn breeders is to have their calres dropped in the spring months of March, April, and May.

2.-A comparison of the data obtained in this study with the data of the Bureau of Crop Estimates for all cattle in 1913, is in close agreement. There was evidence that a limited number of breeders hred cows to calve in January and September for show purposes.

\section{BREEDING AGE OF SHORTHORN HEIFERS}

The age at which Shorthorn heifers should be bred is properly given consideration by practical breeders, for they all agree that the age at which a heifer is bred and at which she calves has a large influence on her usefulness.

Breeders disagree in their opinions and advice on any particular age at which Shorthorn heifers should be bred. They disagree on the probable effects attendant upon early or "late" breeding. Some breeders think early breeding will permanently stunt or dwarf the young dam; others think the effect temporary. Some breeders think the first calf from a young mother is likely to be a weakling while others think late breeding leads to difficulty in securing conception or even to complete barrenness.

The American Shorthorn Breeders' Association has in effect a rule limiting the age at which calves are registered from young dams and a similar rule is adhered to by the Hereford and Aberdeen-Angus associations.

\section{Breed Association Rules}

The rule in force for Shorthorn places the age limit of the heifer at fifteen months old at time of first calving. The rule in force for Aberdeen-Angus, American Aberdeen-Angus Breeders' Association (1919), is eighteen months. The rule for Herefords, as given by the American Hereford Breeders' Association (1900-3), is placed at twenty-seven months.

Data, other than the printed rules of the Shorthorn and Aberdeen-Angus Associations are not available. However, the complete history of the proposal and enactment of the rule governing the registration of calves from Hereford heifers is at hand and is included 
here since it presents the ideas and conditions under which a great body of breeders operate.

The rule in force, Rule IV, of the Hereford Association, has been operative since Dec. 7, 1900 . Previous to that time there were no restrictions with reference to the age of a heifer at the time of dropping her first calf. On November 21, 1900, the Executive Committee (A. H. B. A., 1900-a) for the Hereford Association composed of Thomas Clark, Beecher, Illinois; Chas. Gudgell, of Gudgell and Simpson, Independence, Missouri, and H. H. Clough of Elyria, Ohio, proposed two amendments to be voted upon at the annual meeting of The Hereford Breeders' Association in Chicago, December 7, 1900. The statement of the Executive Committee relative to the proposed amendment governing the age of heifers at time of calving as reported by the Breeders' Gazette for the American Hereford Breeders' Association (1900-6), is as follows:

The proposed amendment appeals to the committee as a remedy for an evil that has grown to serious proportions. This evil is permitting heifer calves to be exposed to bulls and become mothers at very immature ages. To show the degree to which this has been carried will say that applications for entry have been made from mothers only thirteen months old showing they were caught when less than four months old. Most of the breeders where they regulate the breeding of their heifers do not purposely expose them until they are at least twenty months old, so that nearly all the calves dropped from mothers under twenty-seven months old are the result of careless or accidental exposures. This usually comes from the reprehensible practice of allowing the bull and heifer calves to run together either separated from their mothers or with mothers and herd bull. This course entails a very grave element of uncertainty as to the sire, as the chances are that the heifer thus caught was exposed to more than one bull, though this fact may be denied by the owner.

With regard to those calves from abnormally young mothers, "accidents" as they are termed in the Hereford office, the committee has adopted the practice of requiring affidavits as to the facts and circumstances attending the heifers exposure and especially as to the fact that she was not exposed to more than one bull. These affidavits, while the best that can be done under the present rules have not been satisfactory to the committee in that it appears to offer a premium to those who are careless in handling their cattle and reckless in their statement.

Very few breeders, not more than one or two that are now recalled, make a practice of breeding their heifers under eighteen months old. The result of such practice is so well known to all breeders that no comment is needed as to the character of such herds. With the object of remedying this evil by making it a loss, to such as are given to this careless practice, and of further elevating the merit standard of all representatives of the breed, this amendment has met with the approval of the committee.

Proposed Amendment (A. H. B. A., 1900-2) passed December 7, $1900 ; 239$ votes for, and 73 against.

Secretary Kinzer* in reply to a question as to the working of this rule says in part:

* Kinzer, R. J. Letter to author July 24, 1923. 
"It was placed in our by-laws with the idea that heifers should be permitted to at least reach the age of eighteen months before being bred, in order that they might have attained greater growth and not be stunted in their growth by producing a calf at too young an age.

"In the twelve years I have been with the Association, I have heard very little criticism of this rule and I think it generally meets with the hearty approval of the large majority of our Hereford breeders."

\section{Opinions of Practical Breeders}

Warfield (1889) says in regard to the age at which cattle should be bred that it depends upon the breed and maturity of each individual, but that his experience with Shorthorn heifers was that they should be bred at about eighteen months. He says, "Certainly it is rarely for their ultimate good to be bred earlier than that age. If the heifer is small or backward in any way it is often advantageous to delay breeding from one to three months. Much depends upon the time of calving in the development obtained by an animal. It will rarely be found advisable to delay the time of breeding so late as until the heifer is twenty-seven months old. Two years old is late enough to be a little risky and more time may be lost by several services being required to get such a heifer to stand if no more serious evil results. Of course no heifer ought to be pushed into the drains of motherhood until her development is sufficient to warrant it, but few heifers are so backward as not to be quite prepared for the drains of motherhood by the time they are thirty months old."

Allen (1887), the founder of The American Shorthorn Herdbooks and a contemporary of Warfield, says it was his practice to breed heifers at from fifteen to seventeen months old, and that they developed into fine, thrifty young cows in good condition and proved excellent milkers lasting as many years as if bred a season later.

Under advantages of such practice he claimed such cows were more docile, easier handled, and that besides gaining a years profit, the milking function of the cows was stimulated more than if bred to calve at thirty-six months. However, under disadvantages his judgment was that there was a danger of weakening the cow's constitution if the heifer was inclined to be small, and that he would wait even longer than twenty-four months before breeding her.

C. L. Gerlangh (1900), Green County, Ohio, in answer to the question said, "Shorthorn heifers descended from well developed dams and sires and that have had proper care so as to produce a strong 
growth should be bred at eighteen to twenty months old. Then the heifers should be kept growing steadily along until calving." He said he noticed while in Scotland some of the best breeders of Shorthorns bred their heifers at about fifteen months and then let thein drop their second calves at about three and one-half years of age. By this practice they claimed to have very few barren heifers and also had well developed cows.

I. N. Forbes, Marshall County, Illinois, (1900) stated that breeding heifers at twenty to twenty-four months had given better satisfaction than breeding them younger and that no more difficulty was experienced in getting them to breed then, than at from sixteen to eighteen months, the age many other breeders claimed they favored. He claimed that he would rather have a heifer drop her first calf at thirty-six months than at twenty-six months and that some of his best breeding cows were past four years old when they dropped their first calves.

J. G. Robbins and Sons (1900), Horace, Indiana, advised never to let heifers calve before they are thirty to thirty-six months old, but that no rule could be strictly adhered to as some heifers get their growth earlier than others.

T. J. Warnall, (1900) Clay County, Missouri, said to wait until the heifer is grown and that he thought two years the proper age at which to breed most of them, but if the heifer was inclined to be small that he would wait even longer than twenty-four months.

Abram Renick (1900), Clark County, Kentucky, gave his observation that heifers not bred until after two years of age, or that failed to get in calf for a few months after he thought them old enough to breed, invariably made the best cows. He contended that the age at which heifers should be bred depended upon the treatment they had had and the care during pregnancy. His general rule was: "Never breed a heifer less than twenty months old and if by waiting a few months later you can have her calve in the early spring you will profit by the delay."

G. S. Barclay (1900), Muscatine, Iowa, stated that it depended upon the kind of heifer. If the heifer was large and strong he thought it all right for her to have her first calf at twenty-four to thirty months of age, but if she was not well grown or a little under size that she ought to be at least thirty-six months old before calving. His observation was that heifers bred very young are apt to lose a year before they are five years old and that it always interfered with 
their growth. He admitted that they would possibly make as good breeding cows when bred young, but did not believe they ever looked as well, and doubted that they were as valuable breeding cows as heifers bred at a later age.

W. E. Boyden (1900), Washtenaw County, Michigan, said as a rule he began breeding Shorthorn heifers at twenty-three to twentytive months old. If they had been pushed along rapidly and had plenty of flesh and size he thought it good practice to breed at twenty to twenty-one months. He stated he was not in favor of breeding as roung as most breeders for he thought a heifer should have her first two years in which to develop.

Houseman (1900) and McDonald and Sinclair (1909) state that Aberdeen-Angus heifers in Aberdeenshire are bred at eighteen to iwenty-four months and that Shorthorns in Scotland are bred to calve at twenty-four to twenty-six months old. In the case of Herefords they state that some breeders breed heifers at sixteen to eighteen months while others breed them at eighteen to twenty months old.

Potter (1921) advises that western United States range breeders breed heifers at thirty-six months old and if well kept at twenty-four months.

Dan D. Casement (1922) says he breeds Hereford heifers for replacement in his purebred herd at fifteen to eighteen months, but doubts if such practice has anything to recommend it.

Will C. Barnes (1917) states that many range men believe that a range bred heifer bred to calve at twenty to twenty-four months will miss at thirty-six months and fail to bring a calf until fully four years old or older. He asserts that nobody has any facts to prove the correctness of this based upon large numbers of animals under range conditions.

Vaughn (1923) states that in many instances heifers are bred at fifteen to eighteen months but that it is better practice to begin breeding them at about twenty-one months old so that they drop their first calf at about thirty months of age.

Tomhave and Severson (1918), at the Pennsylvania Station, recommenu as a result of breeding experience with Shorthorn and Angus heifers that if heifers are permitted to Arop their first calves before thirty months old, twelve to fifteen months should intervene before they again calve.

Mclamplell (1921)) at tire Fiayes Branch Staion in Kansas, 
compared groups of heifers bred at two and three years old respectively. His results indicate that a large percentage of heifers calving at two years old on a ration composed of roughage alone afterwards proved barren.

The question, "At what age do you breed your he1fers?" was put to a number of Shorthorn breeders. Their replies as given in "Shorthorns in America," for the American Shorthorn Breeders' Association are as follows:

E. J. Thompson and sons, Hurley, S. D. Well matured, z2 months.

John Garden of Weaver and Garden, Wapello, Iowa. Well grown, 15 to 16 months.

J. A. Kilgore, Sterling, Ill. Not under 18 months.

Leslie Smith and Sons, St. Cloud, Minn. 15 to 20 months.

W. C. Rosenberger, Tiffin, Ohio. 20 months.

Eben E. Jones, Rockland, Wisconsin. Bred to calve 30 to 36 months.

J. R. Raby, Gatesville, Texas. 20 to 22 months.

George Sim, Anoka Farm, Waukesha, Wisconsin. 18 to 20 months.

Alex Edgar with J. F. Prather, Williamsville, Ill. 18 to 20 months.

G. H. Prescott and Sons, Tawas City, Michigan. "Juniors" 2 years. "Seniors" 22 months to calve in March. Heifers rested after first calf.

E. B. Thomas, Audubon, Iowa. 16 to 20 months.

D. Warnock and Sons, Loveland, Cal. 18 months.

A. J. Ryden, Abingdon, Ill. 18 to 20 months.

R. H. Scott, Mgr. Lespedeza Farm, Hickory Valley, Tenn. 18 to 20 months.

Wm. Millne with J. W. McDermott, Kahoka, Mo. 18 to 20 months.

E. Ogen and Sons, Maryville, Mo. A normal heifer should calve at 24 to 25 months. They make better mothers and are more dependable.

Frank Brown, Carlton, Oregon. 18 to 24 months.

Thompson Brothers, Carbondale, Kansas. 18 to 22 months.

In spite of these and many other available recommendations there has been no actual determination of what may be considered general practice of the larger number of Shorthorn breeders relative to :iic age at which they mate their heifers.

Additional importance is given such a study when a comparison of the registered calves produced by early and late bred cows is included. 


\section{Statistical Study}

Methods.-Records of Shorthorn heifers calved in 1908 were used. All records of heifers, from the "Active File" calving two or more calves, the first calf having been dropped within forty-eight months from the date of birth of the heifer, were included. A total of 2,500 heifers was obtained for study.

TABLE XVI.-Distribution of 3,047 "Active File" Cows Calving Two or More Calves with Reference to Year of First Calving.

\begin{tabular}{l|r|r|r|r|r|r|r|r|r|r|r|r}
\hline \hline Year & \multicolumn{10}{c}{ Calves per Cow to July 1922} & \multicolumn{1}{c}{} \\
\cline { 2 - 12 } Calved & 2 & 3 & 4 & 5 & 6 & 7 & 8 & 9 & 10 & 11 & Cows \\
\hline 1909 & & 1 & 5 & 6 & 2 & 4 & 3 & 3 & 1 & & 25 \\
1910 & 111 & 129 & 97 & 114 & 127 & 81 & 90 & 61 & 21 & 5 & 759 \\
1911 & 90 & 114 & 139 & 106 & 103 & 71 & 38 & 16 & 1 & & 678 \\
1912 & 68 & 81 & 77 & 63 & 47 & 26 & 6 & 3 & 1 & & 372 \\
1913 & 48 & 37 & 38 & 33 & 13 & 9 & 2 & 1 & & & 181 \\
1914 & 36 & 20 & 24 & 9 & 9 & 2 & & & & & 100 \\
1915 & 18 & 14 & 9 & 3 & & & & & & & 44 \\
1916 & 16 & 5 & 1 & & & & & & & & 22 \\
1917 & 3 & 2 & & & & & & & & & 5 \\
1918 & 4 & & & & & & & & & & 4 \\
1919 & 466 & 494 & 520 & 469 & 427 & 300 & 212 & 114 & 37 & 8 & 3047 \\
\hline Cows & & & & & & & & \\
\hline \hline
\end{tabular}

Table XVI shows the cows from the "Active File" that produced two or more calves per cow 1908 to July 1922. This table is arranged to show the year in which the heifer dropped her first registered calf. It is worthy of note that four cows did not have any calves recorded intil after they were eleven years old. It is obvious that this could hardly be the date of birth of their first calf.

Heifers that dropped their first registered calf within the years 1909 to 1912 inclusive were used. The age of these heifers at calving was computed in months. A heifer dropped within January 1908 and calving in January 1910 was computed as being twenty-four months old.

The age of the heifer when bred was obtained by subtracting nine months from the age at time of calving as above computed. Table XVII and Figure 8 were prepared from these computations. Table XVII gives the age of the 2,500 heifers distributed as to months of age at time of breeding and calving, the number for the month, the per cent of the total and the cumulative per cent. 
TABLE XVII.-Age of 2,500 Shorthorn Heifers in Months at Calving (Number and Per Cent by Months).

\begin{tabular}{|c|c|c|c|c|}
\hline \multicolumn{2}{|c|}{ Age in Months } & \multirow{2}{*}{ Number } & \multirow{2}{*}{ Per Cent } & \multirow{2}{*}{$\begin{array}{l}\text { Per Cent } \\
\text { Cumulative }\end{array}$} \\
\hline Bred & Calved & & & \\
\hline 6 & 15 & 1 & .04 & .04 \\
\hline 7 & 16 & 2 & .08 & .12 \\
\hline 8 & 17 & 4 & .16 & .28 \\
\hline 9 & 18 & 11 & .44 & .72 \\
\hline 10 & 19 & 18 & .72 & 1.44 \\
\hline 11 & 20 & 18 & .72 & 2.16 \\
\hline 12 & 21 & 24 & .96 & 3.12 \\
\hline 13 & 22 & 36 & 1.44 & 4.56 \\
\hline 14 & 23 & 51 & 2.04 & 6.60 \\
\hline 15 & 24 & 87 & 3.48 & 10.08 \\
\hline 16 & 25 & 90 & 3.60 & 13.68 \\
\hline 17 & 26 & 108 & 4.32 & 18.00 \\
\hline 18 & 27 & 107 & 4.28 & 22.28 \\
\hline 19 & 28 & 98 & 3.92 & 26.20 \\
\hline 20 & 29 & 90 & 3.60 & 29.80 \\
\hline 21 & 30 & 108 & 4.32 & 34.12 \\
\hline 22 & 31 & 99 & 3.96 & 38.08 \\
\hline 23 & 32 & 124 & 4.96 & 43.04 \\
\hline 24 & 33 & 110 & 4.40 & 47.44 \\
\hline 25 & 34 & 109 & 4.36 & 51.80 \\
\hline 26 & 35 & 118 & 4.72 & 56.52 \\
\hline 27 & 36 & 147 & 5.88 & 62.40 \\
\hline 28 & 37 & 124 & 4.96 & 67.36 \\
\hline 29 & 38 & 92 & 3.68 & 71.04 \\
\hline 30 & 39 & 78 & 3.12 & 74.16 \\
\hline 31 & 40 & 73 & 2.92 & 77.08 \\
\hline 32 & 41 & 83 & 3.28 & 80.36 \\
\hline 33 & 42 & 61 & 2.44 & 82.80 \\
\hline 34 & 43 & 65 & 2.60 & 85.40 \\
\hline 35 & 44 & 60 & 2.40 & 87.80 \\
\hline 36 & 45 & 72 & 2.88 & 90.68 \\
\hline 37 & 46 & 76 & 3.04 & 93.72 \\
\hline 38 & 47 & 80 & 3.20 & 96.92 \\
\hline 39 & 48 & 77 & 3.08 & 100.00 \\
\hline & Total & 2500 & & \\
\hline
\end{tabular}

An inspection of Table XVII and Figure 8 shows that 165 heifers were bred from six to fourteen months of age, calving by or before the time they were twenty-three months old. These 165 heifers are equivalent to 6.6 per cent of the 2,500. In no instance has any recommendation supporting such eariy breeding been obtained from breeders or literature. Such breeding is usually the result of accidents.

There is such a marked rise on the chart in the number and per cent of the heifers bred at fifteen and sixteen months and calving at twenty-four and twenty-five months that intent on the part of the breeders seem certain. 7.08 per cent or 177 heifers were so bred in these two months as against 165 heifers in the previous nine months.

For the twelve-month period, including heifers fifteen to twenty- 
six months old when bred, 49.92 per cent or 1,248 heifers were bred to calve at twenty-four to thirty-five months old. While there is slight difference in the numbers bred in each of these months there is no marked indication of preference for any one month of age at time of breeding with the possible exception of heifers bred at twentythree months and calving at thirty-two months.

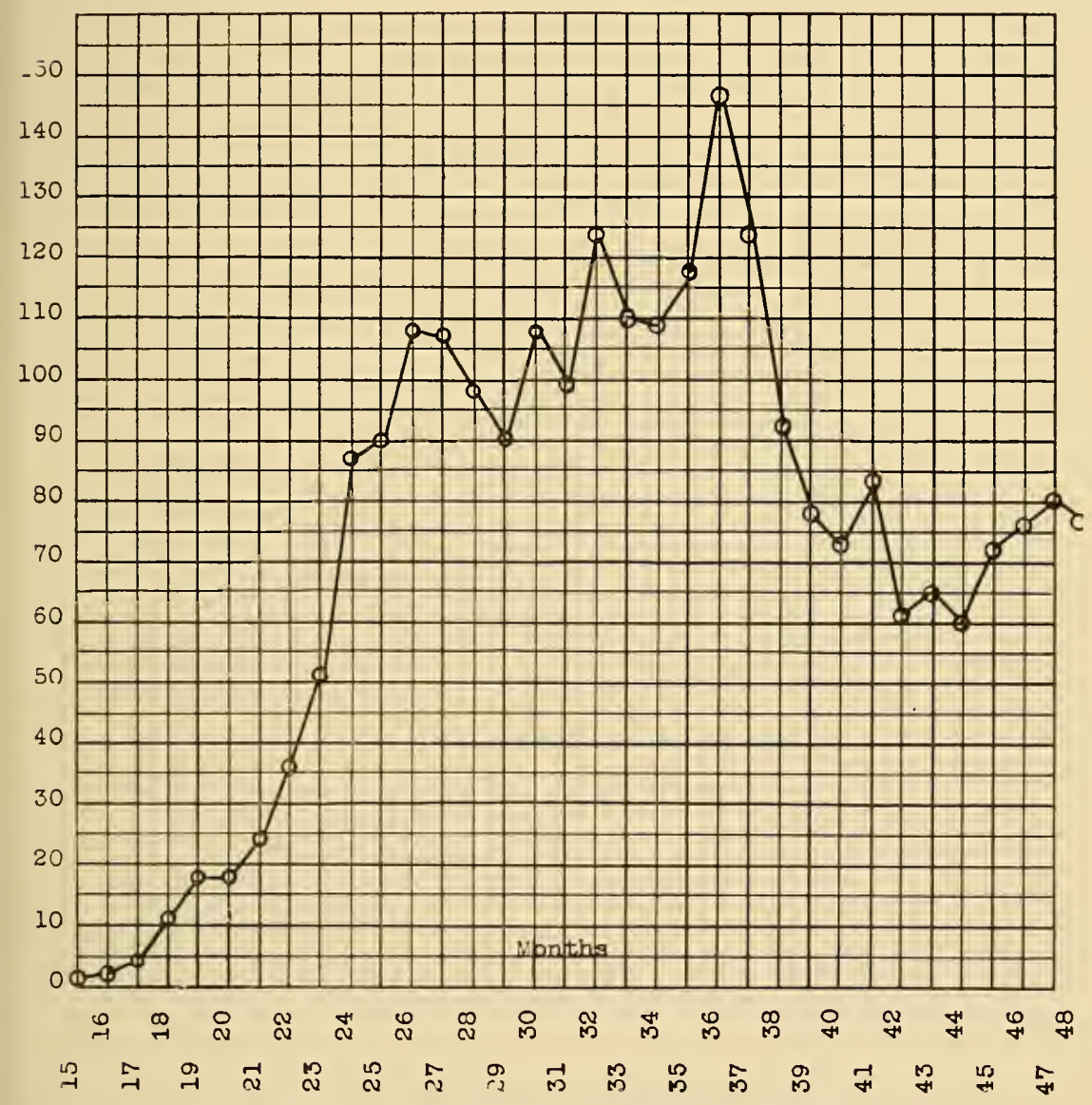

Fig. 8.-Age of 2,500 Shorthorn Heifers at Calving, Showing Number Calving Each Month.

For the twelve-month period, including heifers bred at twentyseven to thirty-eight months old, 40.4 per cent or 1,010 heifers were bred to calve at from thirty-six to forty-one months old. In this instance it appears from a study of the table and the chart that there is a preference on the part of the breeders to breed heifers at twenty- 
seven months old and have them calve at thirty-six months old. It should be noted that there are other possibilities the most likely of which may be the following: Heifers are bred to calve at twenty to twenty-seven months but fail to conceive and are later rebred to calve at from thirty-six to thirty-eight months; or that such heifers conceive and abort or produce dead calves; or that first calves from such matings are not registered.

Of the 2,500 cows under consideration 67.56 per cent of 1659 were bred at fifteen to thirty months old inclusive and calved at twenty-four to thirty-nine months old. From Figure 8 this appears to be the preferred period, and since more than two-thirds of the 2,500 cows are included in this interval the data support the impression.

\section{Influence of Age of Heifers at Calving on Their Breeding Performance}

This study is an attempt to show the effect of extremely early and comparatively late breeding on the number of calves produced per cow compared with heifers bred neither early nor late.

In this study any heifer bred before she was fifteen months old or that calved before she was twenty-four months old is considered as being bred early. Any heifer bred after she was twenty-nine months old or that calved after she was thirty-eight months old is considered as being bred late, and the group falling in between is considered as of average age.

Methods of Study.-The 2,500 heifers included in the previous study form the basis of this study. All heifers in the 2,500 that produced five or more calves were chosen. A total of 1,471 heifers or 58.85 per cent of the 2,500 heifers in the group calving two or more calves was obtained and is included in the data presented in Table XVIII and Figure 9.

Table XVIII is arranged to show the frequency of heifers calving five to eleven calves within each monthly group. From the frequency table and the chart it is apparent that the monthly groups divide into three parts corresponding approximately to the definitions given for early average and late calving groups of heifers. The first division or the early calving group includes heifers calving from sixteen to twenty-three months, inclusive; the second, modal and average group at time of calving includes heifers twenty-four to thirtyseven months inclusive and the third or late calving group includes 
heifers thirty-eight to forty-eight months old at time of calving. Pable XIX summarizes the results of such division.

TABLE XVIII.-1,471 Heifers Calving Five or More Calves, First Calf Dropped 16 to 48 Months.

\begin{tabular}{|c|c|c|c|c|c|c|c|c|c|c|c|}
\hline \multirow{2}{*}{\multicolumn{2}{|c|}{$\frac{1}{\text { Age in Months }}$}} & \multicolumn{2}{|c|}{ Calves } & \multicolumn{2}{|c|}{ Per Cow } & \multicolumn{3}{|c|}{ to July 1922} & \multirow{2}{*}{$\left|\begin{array}{l}\text { Total } \\
\text { Cows }\end{array}\right|$} & \multirow{2}{*}{$\begin{array}{l}\text { Total } \\
\text { Calves }\end{array}$} & \multirow[b]{2}{*}{$\begin{array}{l}\text { Average } \\
\text { Calves }\end{array}$} \\
\hline & & 5 & 6 & 7 & 8 & 9 & 10 & 11 & & & \\
\hline$\overline{7}$ & 16 & & & & 1 & & & & 1 & 8 & 8.00 \\
\hline 8 & 17 & & & & & 1 & & & 1 & 9 & 9.00 \\
\hline 9 & 18 & 1 & 2 & 1 & 2 & & & & 6 & 40 & 6.66 \\
\hline 10 & 19 & 2 & 1 & 3 & & 3 & & & 9 & 64 & 7.11 \\
\hline 11 & 20 & 3 & 2 & 1 & 1 & 2 & 2 & & 11 & 80 & 7.27 \\
\hline 12 & 21 & 5 & 4 & 4 & 4 & 1 & 2 & & 20 & 138 & 6.90 \\
\hline 13 & 22 & 7 & 3 & 6 & 1 & 5 & 1 & 1 & 24 & 169 & 7.04 \\
\hline 14 & 23 & 3 & 7 & 6 & 5 & 4 & 3 & 1 & 29 & 216 & 7.44 \\
\hline 15 & 24 & 12 & 15 & 7 & 11 & 9 & 4 & 2 & 60 & 430 & 7.16 \\
\hline 16 & 25 & 13 & 13 & 11 & 10 & 5 & 2 & 1 & 55 & 376 & 6.83 \\
\hline 17 & 26 & 13 & 17 & 12 & 14 & 8 & 3 & & 67 & 465 & 6.94 \\
\hline 18 & 27 & 27 & 14 & 11 & 8 & 5 & 3 & 1 & 69 & 446 & $-6.46 \dagger$ \\
\hline 19 & 28 & 15 & 16 & 10 & 12 & 5 & 1 & & 59 & 392 & -6.64 \\
\hline 20 & 29 & 7 & 17 & 8 & 9 & 7 & 4 & & 52 & 368 & 7.00 \\
\hline 21 & 30 & 19 & 18 & 13 & 6 & 8 & 3 & 1 & 68 & 455 & 6.69 \\
\hline 22 & 31 & 18 & 20 & 8 & 14 & 6 & 3 & & 69 & 462 & 6.69 \\
\hline 23 & 32 & 14 & 22 & 20 & 15 & 1 & 3 & 2 & 77 & 523 & 6.79 \\
\hline 24 & 33 & 18 & 19 & 20 & 8 & 4 & 3 & 2 & 74 & 496 & 6.70 \\
\hline 25 & 34 & 16 & 15 & 15 & 18 & 5 & 1 & & 70 & 474 & 6.77 \\
\hline 26 & 35 & 20 & 19 & 16 & 8 & 2 & 1 & & 66 & 418 & -6.33 \\
\hline 27 & 36 & 34 & 18 & 19 & 16 & 3 & 5 & & 95 & 616 & -6.48 \\
\hline 28 & 37 & 20 & 22 & 19 & 6 & 2 & 3 & 1 & 73 & 472 & -6.46 \\
\hline 29 & 38 & 14 & 7 & 10 & 11 & 5 & & & 47 & 315 & 6.70 \\
\hline 30 & 39 & 12 & 7 & 10 & 7 & 3 & & & 39 & 255 & -6.53 \\
\hline 31 & 40 & 12 & 7 & 11 & 7 & 6 & & 1 & 44 & 300 & 6.81 \\
\hline 32 & 41 & 10 & 13 & 6 & 3 & 5 & 1 & & 38 & 249 & -6.55 \\
\hline 33 & 42 & 10 & 5 & 7 & 3 & 3 & 3 & & 31 & 210 & 6.77 \\
\hline 34 & 43 & 11 & 12 & 7 & 8 & 2 & & & 40 & 258 & -6.45 \\
\hline 35 & 44 & 6 & 9 & 8 & 8 & 2 & & & 33 & 222 & 6.72 \\
\hline 36 & 45 & 10 & 10 & 2 & 7 & 4 & $=$ & & 33 & 216 & -6.54 \\
\hline 37 & 46 & 12 & 16 & 6 & 8 & & 1 & & 43 & 272 & -6.32 \\
\hline 38 & 47 & 13 & 6 & 7 & 7 & 1 & & & 34 & 215 & -6.35 \\
\hline 39 & 48 & 14 & 7 & 6 & 7 & & & & 34 & 210 & -6.17 \\
\hline & Cows & 391 & 363 & 291 & 245 & 117 & 52 & 13 & 1471 & 9839 & $6.69 *$ \\
\hline
\end{tabular}

$\div$ Groups marked minus (-) are belnw the general average for the $1,4 i 1$.

Result of computation $\frac{\text { Total Calves }}{\text { Total Cows }} \frac{9,839}{1,471}=6.69$ 
TABLE XIX.-Comparison of Early, Medium, and Late Calving Heifers Showing Average Number of Calves Per Cow by Groups.

\begin{tabular}{|c|c|c|c|c|c|c|c|c|c|c|c|c|}
\hline \multicolumn{2}{|c|}{ Age in Months } & \multicolumn{2}{|c|}{ Calves } & Per & Cow to & \multicolumn{3}{|c|}{ July, 1922} & \multirow{2}{*}{ 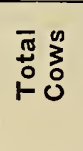 } & \multirow{2}{*}{\begin{tabular}{l}
$\bar{\pi}$ \\
$\stackrel{0}{\circ}$ \\
$\vdash$ \\
\hdashline \\
$\mathcal{J}$
\end{tabular}} & \multirow{2}{*}{ 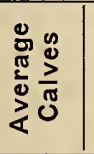 } & \multirow{2}{*}{ 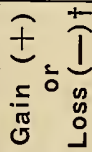 } \\
\hline Bred & Calved & 5 & 6 & 7 & 8 & 9 & 10 & 11 & & & & \\
\hline $7 \overline{7-14}$ & $16-23$ & 21 & 19 & 21 & 14 & 16 & 18 & 2 & 101 & 724 & 7.17 & +.48 \\
\hline $15-28$ & $24-37$ & 249 & 245 & 189 & 155 & 70 & 39 & 10 & 954 & 6393 & $6.70^{\circ}$ & +.01 \\
\hline $29-39$ & $38-48$ & 124 & 99 & 80 & 76 & 31 & 5 & 1 & 416 & 2722 & 6.54 & -.14 \\
\hline
\end{tabular}

$\doteqdot$ Based on Average

*Result of computation $\frac{\text { Total Calves }}{\text { Total Cows }} \frac{9,839}{1,471}=6.69$

Table XIX shows that the 101 heifers calving in the early group fifteen to twenty-three months old produced an average number of 7.17 calves per cow. A total of 954 heifers calving in the modal group twenty-four to thirty-seven months old produced an average of 6.70 calves per cow and 416 heifers calving in the late group thirtyeight to forty-eight months old produced 6.54 calves per cow. Figure 9 shows the average number of calves per cow and the cows in each of the monthly groups sixteen to forty-eight months inclusive.

As was to be expected in such a division the middle or modal group with the largest number of cows produced the approximate average number of calves per cow obtained for the whole group. The early bred heifers produced an excess of one-half calf per cow above the average number for the whole group, while the late bred heifers fell slightly below the average. The difference in the average number of calves per cow in favor of the early bred group over the late bred group amounts to two-thirds calf per cow.

The early-bred group had an advantage in time or a longer breeding life over the late bred group. This time advantage was determined by computing the mean calving age of each group and calculating the difference. The approximate mean calving age of Group I as presented in Table XX, is twenty-one months; Group II, thirtyone months, and Group III, forty-three months. The early calving group had ten months advantage over the modal group and twentytwo months advantage over the late calving group. There can hardly ic any question but that this time advantage of the early calving yroup over the late calving group was an important factor in bringing about the higher average number of calves per cow for the early calving group. 
Cows

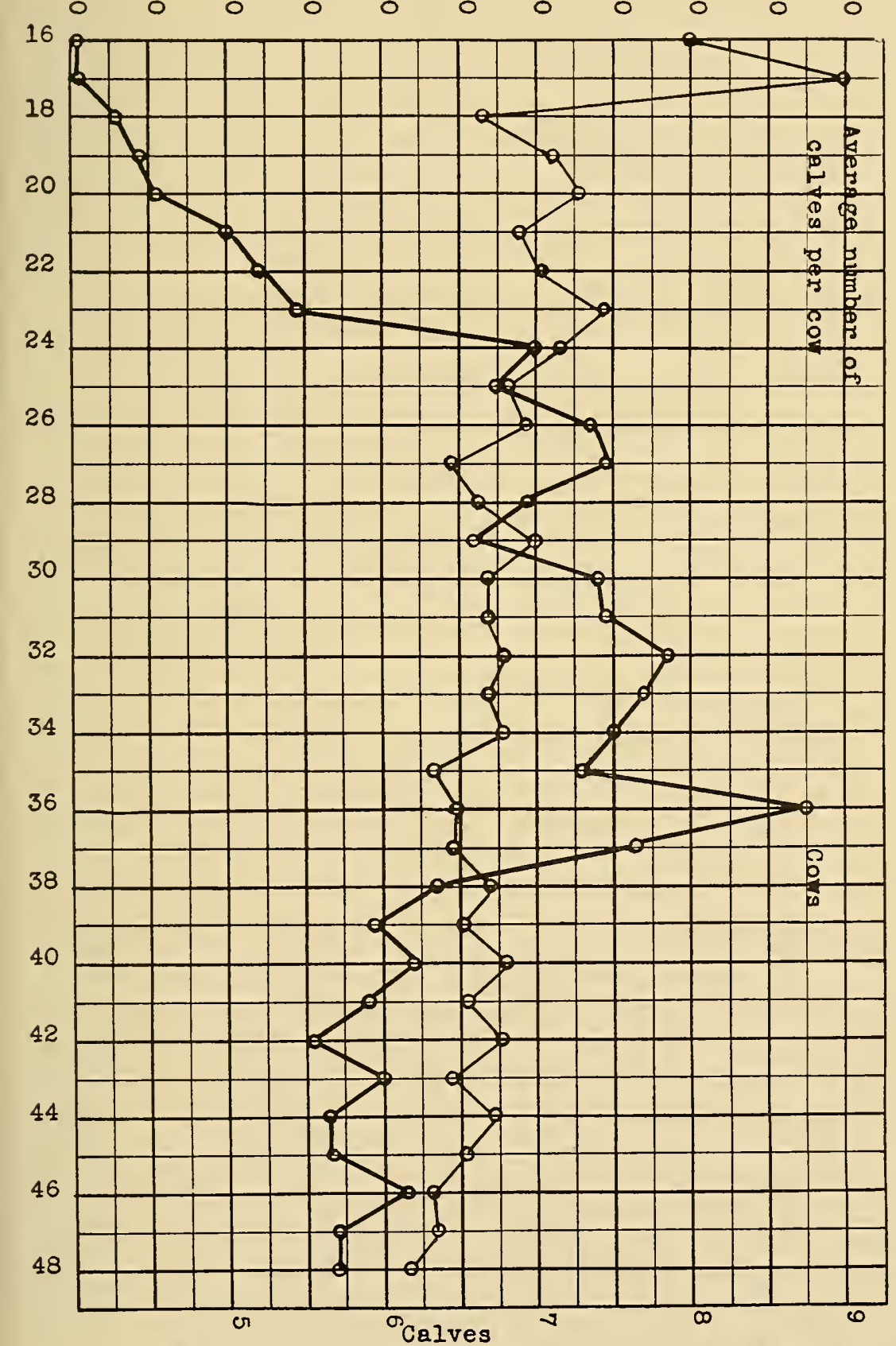

Fig. 9.-Heifers Calving Five or More Calves; First Calf Dropped at 16 to 48 Months; Showing Average Calves per Cow. 


\begin{tabular}{|c|c|c|c|}
\hline$\Xi$ & $\Xi$ & $\mapsto$ & 옿 \\
\hline ڤే & 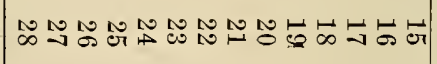 & 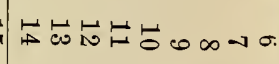 & 总 \\
\hline 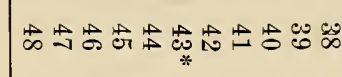 & 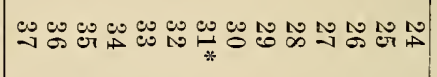 & 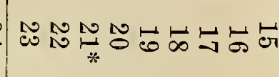 & 覀 \\
\hline 거 & 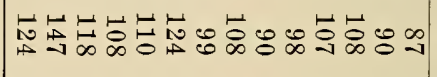 & 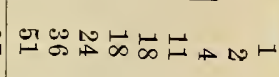 & 蓘 \\
\hline 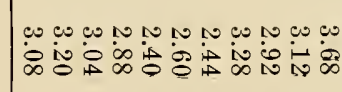 & 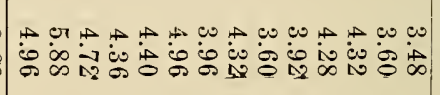 & 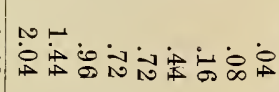 & 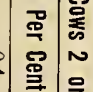 \\
\hline 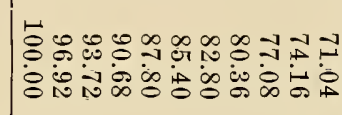 & 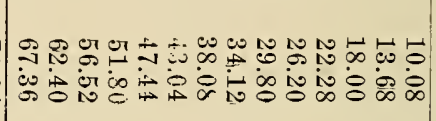 & 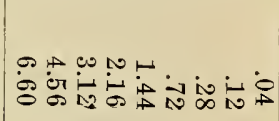 & 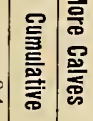 \\
\hline 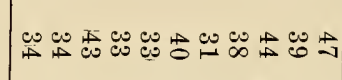 & 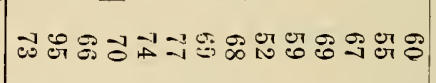 & 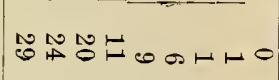 & \\
\hline 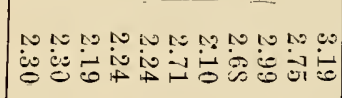 & 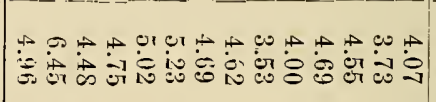 & 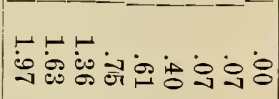 & 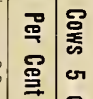 \\
\hline 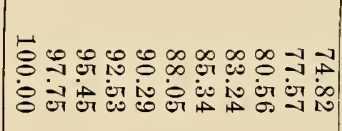 & 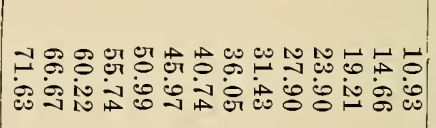 & 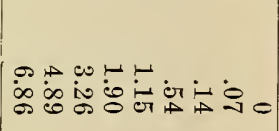 & 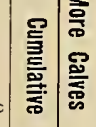 \\
\hline 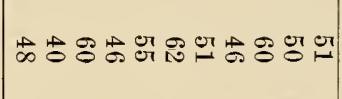 & 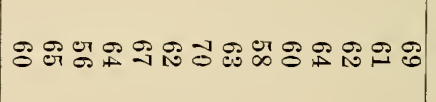 & 걱 & 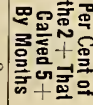 \\
\hline$\stackrel{\infty}{\sigma}$ & $\stackrel{\vec{c}}{\overparen{\theta}}$ & $\vec{g}$ & 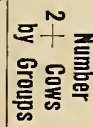 \\
\hline$\stackrel{\leftrightarrow}{\sigma}$ & $\stackrel{\infty}{\oplus}$ & s & 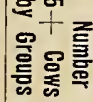 \\
\hline $\begin{array}{l}1 \\
\stackrel{1}{\infty} \\
\dot{\infty}\end{array}$ & $\begin{array}{l}\substack{i \\
\infty \\
\infty} \\
\stackrel{\infty}{\infty}\end{array}$ & 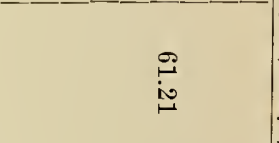 & 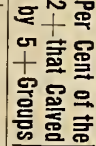 \\
\hline $\begin{array}{l}1 \\
\stackrel{-1}{\infty} \\
-1\end{array}$ & $\begin{array}{l}+ \\
0.0 \\
\dot{c} \\
\dot{c} \\
c\end{array}$ & 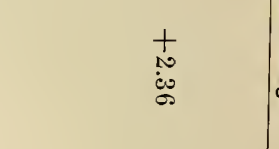 & 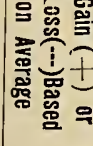 \\
\hline
\end{tabular}


Table XX is constructed and presented to show the per cent of the two or more calf cows that calved five or more calves. As previously noted 58.85 per cent of the two-plus cows calved five or more calves per cow. Table XX shows the percentage of the two-plus cows that calved five calves by month and by groups, early, modal, and late. Group 1 or early calving cows exceeded the average per cent of two-plus cows that calved five or more calves by 2.36 per cent. Group II exceeded the arerage by 3.95 per cent, and Group III, or the late bred group, fell below the average percentage by 7.87 per cent.

These data clearly show that while early calving may have other drawbacks it does not necessarily result in such cows being discarded because of barrenness or because they do not produce numbers of calves the owners think worthy of registration. Almost as great a perecentage of the early bred group of cows had five or more calves as of the modal group. It is worthy of note however that a very small number of cows were found that calved even one calf per cow before they were fifteen months old. Table XX shows that no monthly group up to the one including heifers fifteen months old even approximated the number of cows found in the modal gromp.

Table XX also shows that the high average per cent of two-plus cows that produced five or more calves is dependent upon the groups of heifers twenty to twenty-three months old at time of calving rather than on younger heifers. The variation of numbers of two-plus cows producing five or more calyes per cow by months in Group II amounts to 14 per cent, Group II, 22 per cent, and Group I, 83 per cent. Group II according to the data gives by far the best results.

Gronp III with the lowest percentage of cows that went on and produced five or more registered calves again demonstrates the effect of the loss of time on the number of calves produced by late bred heifers. It may or may not be true that difficulty in securing conception or that partial or total barrenness results in enough cases to cause a marked decline in the number of two-plus cows that bred on and produced five or more calves. In any event this much is certain: The two-plus cows in Group III with an approximate mean age of forty-three months at time of first calving had more than ten years time, up until July, 1922, in which to produce five or more calves per cow and a markedly lower percentage of them did so produce when compared with groups bred earlier.

It must be admitted that the two-plus cows of Group I had approximately two years more time. and Group II, one year more time 
than Group III in which to produce five or more calves, but it is not necessarily true that this time interval is the most probable reason why Group III did not approximate more closely the performance of Groups I and II. As a matter of fact the probabilities are that more cows in Group III proved shy breeders or developed into barren cows after a time. It is also probable that they were late developing and maturing cows proving unsatisfactory producers of registered calves and enough of them were discarded before producing five calves to account for the materially lower percentage as found. In any event these data show that a smaller number of the two-plus cows of Group III went on and produced five or more calves.

\section{Summary}

1.- Records of 2,500 heifers that had calved at least twice, and whose first registered calf had been dropped between the ages of fifteen to forty-eight months inclusive were obtained to study the practice of breeders with reference to the age they mated their heifers. The data obtained indicate that there is a wide range of age over which heifers drop calves, but that the general practice of breeders as found from the data is to breed heifers at from fifteen to thirty months of age and to have them calve at from twenty-four to thirtynine months of age. Of the heifers studied 67.56 per cent were found to have dropped their first registered calf within the above mentioned interval.

2.-There is evidence from the data of a slight preference in favor of breeding heifers to calve at thirty-one to thirty-six months inclusive rather than at twenty-four to thirty months inclusive, but there is a probability that cows were included in the thirty-one to thirty-six month old groups that had been previously bred or that had dropped an unregistered calf with a result of seeming to indicate a preference for late breeding and calving rather than early.

3.-Although instances of calving as early as at fifteen to seventeen months were found, less than one per cent of the 2,500 cows were so bred. There is ample evidence from the data to warrant the statement that breeders do not intentionally breed their heifers in any considerable number before the heifers are a year old, and only 6.6 per cent of the 2,500 heifers studied were bred before they were fifteen months old.

4.- - Heifers that calved before they were twenty-four months old produced an average of 7.17 registered calves as against an average 
of 6.54 registered calves for heifers thirty-eight to forty-nine months old.

5.-It was found from these data that cows that had produced two registered calves, calving their first calf after they were thirtycight months old proved less certain to calve an average of five or more registered calves per cow than cows that had produced at least two calves the first registered calf having been dropped before they were thirty-eight months old. 


\section{BIBLIOGRAPHY}

AMERICAN ABERDEEN-ANGUS BREEDERS' ASSOCIATION

1919. RULES. Amer. Aberdeen-Angus Herdbook 30: viii.

AMERICAN HEREFORD BREEDERS' ASSOCIATION

1900-a. REPORT OF ANNUAL MEETING; EXECUTIVE COMMITTEE. Amer. Hereford Record 23: 3, and 543.

1900-b. PROPOSED CHANGE IN HEREFORD REGISTRATION. Breeders' Gazette 38: 750.

AMERICAN SHORTHORN BREEDERS' ASSOCIATION

1918. IMPORTANT RULES IN HERD MANAGEMENT. Shorthorns in America. July 1, p 26.

1924. HOPE TO IMPROVE BEEF CATTLE CLASSES. Chicago Daily Drovers' Jour. March 12.

ALLEN, LEWIS F.

1887. AMERICAN CATTLE. 260-261.

ASHTON, JOHN

I922. HEREFORD, SHORTHORN, AND ABERDEEN-ANGUS SALES. Breeders' Gazette 81: 219.

BARNES, WILL C.

1917. UNCLE SAM, RANGE COWMAN. Breeders' Gazzette 52: 204.

BARCLAY, C. S.

1900. AGE TO BREED HEIFERS. Breeders' Gazette 38: 749-750.

BOYDEN, W. E.

1900. AGE TO BREED HEIFERS. Breeders' Gazette 38: 749-750.

CASEMENT, DAN D.

1922. THE WORLD'S GREATEST BUSINESS. Breeders' Gazette 81: 398.

CURTIS, C. F.

1918. WHEN YOU LAY THE FOUNDATION. Shorthorns in America. October, p 7.

FORBES, I. N.

1900. AGE TO BREED HEIFERS. Breeders' Gazette 38: 749-750.

GERLAUGH, C. L.

1900. AGE TO BREED HEIFERS. Breeders' Gazette 38: 749-750.

HOUSEMAN, WM.

1900. CATTLE BREEDS AND MANAGEMENT. Ed. 8, 177-217.

MARSHALL, F. H. A.

1922. PHISIOLOGY OF REPRODUCTION. Ed. 2, p 43.

MCCAMPBELL, C. W.

1920. PROCEEDINGS. Amer. Soc. of Animal Production. 12-14.

MCDONALDS, JAS, and SINCLAIR, JAS.

1909. HISTORY OF ABERDEEN ANGUS CATTLE. 455-480. 
MUMFORD, F. B.

1920. THE BREEDING OF ANIMALS. P 53.

PLUMB, C. S.

1904. LITTLE SKETCES OF FAMOUS BEEF ANIMALS. 21-23, 51-54

POTTER, E. L., and others

1921. WESTERN LIVESTOCK MANAGEMENT. 60-61, 113-114.

RAY, S. H.

1917. PRODUCTION OF BABY BEEF. U. S. Dept. Agr. Far. Bul.

RENICK, ABRAM

1900. AGE TO BREED HEIFERS. Breeders' Gazette. 38: 749-750.

ROBBINS, J. G., and Sons

1900. AGE TO BREED HEIFERS. Breeder's' Gazette. 38: 749-750.

ROSS, P. G.

1922. ON HERD MANAGEMENT. Breeders' Gazzette. 81: 793.

SHAW, T.

1909. THE MANAGEMENT AND FEEDING OF CATTLE. 1-38, 90-102.

TORMEY, J. L.

1923. SHORTHORNS HAVE GOOD YEAR. Shorthorn World. Dec. 25, p 72.

TOMHAVE, W. H., SEVERSON, B. O., and COEHEL, W. A.

1918. Penn. Exp. Sta. Buls. 118, 138, 150.

VAUGHN, H. W.

1923. TYPES AND MARKET CLASSES OF LIVESTOCK. Ed. 9, p 161.

WARFIELD, WM.

1889. CATTLE BREEDING. 336-337.

1884. A HISTORY OF IMPORTED SHORTHORNS. 776 p.

WARNALI, T. J.

1900. AGE TO BREED HEIFERS. Breeders' Gazette 38: 749-750.

WENTWORTH, E. N., MUNNECKE, V. H., and CROSS, THOS.

1923. PROGRESSIVE BEEF CATTLE RAISING. p 12.

WENTWORTH, E. N.

1921. MONTHLY LTTER TO ANIMAL HUSBANDMEN. Armour's Livestock Bureau, Apr. 21.

UNITED STATES DEPARTMENT OF AGRICULTURE

1922. FOOD ANIMALS AND MEAT CONSUMPTION IN THE UNITED STATES. Cir. 241. Sept. 



\section{HECKMAN}

BINDERY INC.

\section{JUNE 99}

Bound -To-Please N. MANCHESTER
INDIANA 46962 
20

ton

(1)

(in)

(H)

W:

1.

(9)

gan

$\left(\frac{1}{2}\right)$

is

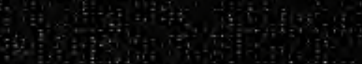

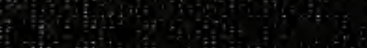

(4)

(5)

(H)

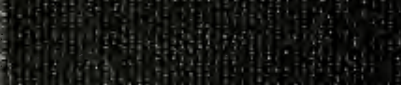
(1)

10

matand

tot.

14.

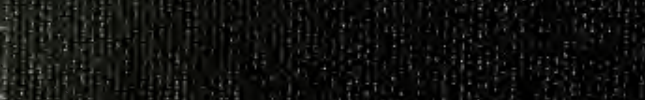

